\title{
TLR9 Signaling in HCV-Associated Atypical Memory B Cells Triggers Th1 and Rheumatoid Factor Autoantibody Responses
}

Cloé Comarmond ${ }^{1,2,3,4,5^{*}}$, Valérie Lorin ${ }^{4,5^{*}}$, Cindy Marques ${ }^{3,4,5^{*}}$, Anna Maciejewski-Duval ${ }^{1,2,3}$, Nizar Joher ${ }^{4,5}$, Cyril Planchais ${ }^{4,5}$, Maxime Touzot ${ }^{6,7}$, Lucie Biard ${ }^{8}$, Thierry Hieu ${ }^{4,5}$, Valentin Quiniou $^{1,2}$, Anne-Claire Desbois ${ }^{1,2,3}$, Michelle Rosenzwajg ${ }^{1,2}$, David Klatzmann ${ }^{1,2,3}$, Patrice Cacoub $^{1,2,3}$, Hugo Mouquet ${ }^{4,5 \#}$, David Saadoun ${ }^{1,2,3 \#}$

1Sorbonne Université, INSERM UMR_S 959, Immunologie-ImmunopathologieImmunotherapie, i3 and Département Hospitalo-Universitaire InflammationImmunopathologie-Biotherapie, i2B, F-75651 Paris, France; ${ }^{2}$ AP-HP, Groupe Hospitalier PitiéSalpêtrière, Service de Biothérapie, F-75013, Paris, France. ${ }^{3}$ AP-HP, Groupe Hospitalier PitiéSalpêtrière, Département de Médecine Interne et Immunologie Clinique, F-75013, Paris, France. ${ }^{4}$ Laboratory of Humoral Immunology, Department of Immunology, Institut Pasteur, Paris, France; ${ }^{5}$ INSERM U1222, Paris, France. ${ }^{6}$ INSERM U932, 26 rue d'Ulm, 75005 Paris, France; Institut Curie, Section Recherche, 26 rue d'Ulm, 75005 Paris, France; 'Laboratoire d'Immunologie Clinique, Institut Curie, 26 rue d'Ulm, 75005 Paris, France. ${ }^{8}$ AP-HP, SBIM, Hôpital Saint-Louis, Université Paris Diderot, Paris 7, Paris, France; INSERM, ECSTRA Team, CRESS UMRS 1153, 75010, Paris, France

* The authors contributed equally to this work as co-first authors.

"The authors contributed equally to this work as co-senior authors.

Corresponding authors: Hugo Mouquet, PhD, Laboratory of Humoral Response to Pathogens, Institut Pasteur, 28 rue du Docteur Roux, 75015 Paris, France; Phone +33(0)140613612; Fax +33(0)1 44389165; E-mail, hugo.mouquet@pasteur.fr., and David Saadoun, MD, PhD, Département de Médecine Interne et d'Immunologie Clinique' INSERM, UMR_S 959, Hôpital Pitié-Salpêtrière, 83 boulevard de l'hôpital, 75013 Paris ; Phone: +33(0)142178009; Fax : +33(0)142178033 ; E-mail : david.saadoun@aphp.fr. 
Keywords: Hepatitis C virus; cryoglobulinemia vasculitis; atypical memory B cells

Number of figures and tables: 7 figures, 1 table and 2 supplementary figures

Conflict of interest statement: The authors declare no competing financial interests, and no personal conflicts of interest.

Financial support statement: This work was supported by the ANRS (CSS4 AO 2014-2).

Authors contributions: H.M. and D.S. conceived the study. D.K., P.C., H.M. and D.S. supervised the work. C.C., V.L., C.M., A-C. D., N.J., C.P., A. M-D., M.T., T.H., V.Q., M.R. and H.M. performed experiments and analyzed data. C.C., H.M. and D.S. wrote the manuscript with contributions from all the authors. 


\section{Abstract}

Background \& Aims: Hepatitis C virus (HCV) infection contributes to the development of autoimmune disorders such as cryoglobulinemia vasculitis (CV). However, it remains unclear why only some HCV-infected individuals develop CV. HCV-CV is characterized by expansions of anergic $\mathrm{CD} 19^{+} \mathrm{CD} 27^{+} \mathrm{CD} 21^{\text {low/- }}$ atypical memory B cells (AtM). Here, we report the mechanisms by which AtM participate to HCV-associated autoimmunity.

Methods: Phenotype and function of peripheral AtM were studied by multi-color flow cytometry and co-culture assays with effector T cells and regulatory $\mathrm{T}$ cells in twenty chronically HCVCV patients, 10 chronically HCV-infected patients without CV and 8 healthy donors. We performed gene expression profile analysis of AtM stimulated or not by TLR9. Immunoglobulin gene repertoire and antibody reactivity profiles of AtM-expressing IgM antibodies were analyzed following single B cell FACS sorting and expression-cloning of monoclonal antibodies.

Results: We show Tbet $^{+} \mathrm{CD} 11 \mathrm{c}^{+} \mathrm{CD} 27^{+} \mathrm{CD} 21^{-}$AtM B-cell expansions in HCV-CV patients as compared to HCV controls without CV. TLR9 activation of AtM induces a specific transcriptional signature centered on TNFa overexpression, and an enhanced secretion of TNFa and rheumatoid factor-type IgMs in HCV-CV patients. AtM stimulated through TLR9 promote type 1 effector $\mathrm{T}$-cell activation and reduce the proliferation of $\mathrm{CD} 4^{+} \mathrm{CD} 25^{\text {hi }} \mathrm{CD} 127^{-}$ ${ }^{\text {llow FoxP3 }}{ }^{+}$regulatory T cells. AtM expansions display intraclonal diversity with immunoglogulin features of antigen-driven maturation. AtM-derived IgM monoclonal antibodies do not react against ubiquitous autoantigens or HCV antigens including NS3 and E2 proteins. Rather, AtMderived antibodies target unique epitopes on the human IgG Fc region and possess rheumatoid factor activity.

Conclusion: Our data strongly suggest a central role for TLR9 activation of AtM in driving HCV-CV autoimmunity through rheumatoid factors production and type $1 \mathrm{~T}$-cell response. 


\section{Introduction}

Chronic HCV infection is associated with extrahepatic complications that are largely immunologically driven. Among those, cryoglobulinaemia and its clinical sequelae hold the strongest association. Cryoglobulins are readily detectable in $40-60 \%$ of $\mathrm{HCV}$-infected patients (1-3), whereas cryoglobulinaemia vasculitis (CV) develops in only $5-10 \%$ of the cases $(4,5)$. The presence of autoantibodies and $T$ cells in vascular infiltrates as well as the observation that specific HLA alleles confer susceptibility to CV in HCV-infected patients support the autoimmune nature of this virus-associated pathology $(6,7)$. CV pathophysiology depends on the interaction between HCV and lymphocytes that directly modulates B- and Tcell function, which ultimately leads to the polyclonal activation and expansion of B cells producing rheumatoid factors $(\mathrm{RF})(1,8)$. We previously reported abnormal immune responses mediated by T cells in HCV-CV patients, with a quantitative defect in regulatory T cells (Tregs) (6), and a Th1 polarization $(9,10)$. HCV infection has been associated with lymphoproliferations, which likely results from an indirect process following the chronic antigenic stimulation of a limited pool of preexisting autoreactive B cells. It has been proposed that persistently high levels of HCV-containing immune complexes stimulate the proliferation of RF-bearing B cells, but the precise antigen(s) and stimulatory mechanisms have remained elusive. We and others previously identified a clonal expansion of $C D 27^{+} \lg M^{+} C D 21^{\text {low/- }}$ memory B cells, referred as activated or atypical memory B cells (AtM), in HCV-associated cryoglobulinemia vasculitis (HCV-CV) $(11,12)$. AtM are clonal or clonally related, and mainly express $\mathrm{V}_{\mathrm{H}}$ 1-69 $\mathrm{IgH}$ gene, which is also highly prevalent in HCV-associated lymphoproliferations (11-13). These clonal cells have a decreased expression of the complement receptor 2, CD21, which mirrors an anergy state $(14,15)$. AtM are prone to undergo apoptosis $(11,13)$, do not proliferate upon BCR stimulation but respond to TLR9 agonist $\mathrm{CpG}$ by expressing activator and proliferative markers $(11,13)$. Anergy is a well-known regulation mechanism for maintaining immune tolerance of autoreactive cells $(14,15)$. Indeed, AtM in HCV-CV produced somatically mutated RF autoantibodies (16), and are not remove from the B-cell repertoire. However, it remains unclear why only some HCV-infected individuals 
develop CV, and why anergy mechanisms fail to prevent the NHL development in some HCVCV patients.

In this work, we characterized the mechanisms by which AtM participate to HCVassociated autoimmunity. We show that TLR9-stimulated AtM secrete TNFa and IgMs with rheumatoid factor activity in HCV-CV patients. Stimulated AtM have a specific transcriptional signature centered on TNFa overexpression, promote the activation of Th1 cells and conversely, reduce Tregs proliferation. We found that AtM antibodies did not cross-reactive against HCV antigens but possessed rheumatoid factor activity. Taken together, our data suggest a central role for TLR9 signalling in AtM, in driving tolerance breakage underlying HCV-CV development. 


\section{Methods}

\section{Patients}

Twenty patients with HCV-CV and ten patients with HCV were included (Table 1). All had positive HCV RNA. HCV viral load was quantified using the Abbott HCV RealTime assay (Abbott) with a lower detection limit of $12 \mathrm{IU} / \mathrm{ml}$. Patients with active HCV vasculitis clinically were defined as previously described (17). The study was approved by the institutional ethics committee of La Pitié-Salpetrière Hospital and was performed in accordance with the Declaration of Helsinki. All participants provided informed consents.

\section{Cell isolation}

PBMCs were obtained by Ficoll-separation, and $C D 19^{+} \operatorname{lgM}{ }^{+} C D 27^{+} C D 21^{- \text {low }}$ (AtM), CD19+ $\operatorname{lgM}{ }^{+} \mathrm{CD} 27^{+} \mathrm{CD} 21^{+}$memory B cells, CD4 ${ }^{+} \mathrm{CD} 25$ effector $T$ cells and $\mathrm{CD} 4{ }^{+} \mathrm{CD} 25^{\mathrm{hi}} \mathrm{CD} 127^{-}$ llow regulatory T cells were isolated by FACS using a FACSAria instrument (Becton Dickinson). Flow cytometric analysis of isolated B and T cell subpopulations consistently showed purity of $>95 \%$.

\section{Cell culture}

Purified B and T cells were cocultured in complete RPMI1640-L-glutamine, and supplemented with $10 \%$ FBS and penicillin/streptomycin (100 U/mg/ml) (Sigma-Aldrich). Isolated CD4 ${ }^{+} \mathrm{CD} 25^{-}$ effector T cells or $\mathrm{CD} 4^{+} \mathrm{CD} 25^{\text {hi }} \mathrm{CD} 127^{- \text {llow }}$ regulatory $\mathrm{T}$ cells were cultured for $72 \mathrm{~h}$ either alone or $1: 1$ with sorted AtM B cell and stimulated with human T-activator CD3/CD28 (Dynabeads) in presence or absence of $1 \mathrm{ug} / \mathrm{ml} \mathrm{CpG}$ (Invivogen). For cytokine detection IFNy, TNFa and IL$17 \mathrm{~A}$ among $\mathrm{CD} 4{ }^{+} \mathrm{CD} 25$ effector $\mathrm{T}$ cells in coculture with AtM stimulated or not by CpG, PMA (50 ng/ml), ionomycin (250 ng/ml) (Sigma-Aldrich), and brefeldin A (BD Biosciences) were added for the last $6 \mathrm{~h}$ of culture.

\section{T-cell proliferation assay}


Following FACS sorting, T cells were loaded with 0.4 mM CFSE (Thermo Fisher Scientific) for $5 \mathrm{~min}$ at $37^{\circ} \mathrm{C}$ and cultured as previously described $(11,17)$. Cultured $\mathrm{CD} 4^{+} \mathrm{CD} 25^{\text {hi }} \mathrm{CD} 127^{- \text {-llow }}$ regulatory $\mathrm{T}$ cells were analyzed for cell division using flow cytometry after $72 \mathrm{~h}$ of coculture with AtM stimulated with CpG 1 mg ODN 2006 Type B CpG oligonucleotide - Human TLR9 ligand (InvivoGen). The concentration of $\mathrm{CpG}$ was $1 \mu \mathrm{g} / \mathrm{ml}$. We used anti-TNFa (ThermoFisher, clone 28401) at $0.05 \mu \mathrm{g} / \mathrm{ml}$.

\section{Flow cytometry analysis}

PBMCs were stained for $30 \mathrm{~min}$ at $4^{\circ} \mathrm{C}$ with the following mouse monoclonal antibodies: for $\mathrm{B}$ cells; FITC- or PCy7-conjugated anti-CD21, PE- or APC-conjugated anti-CD27, APCconjugated anti-lgM, energy-coupled dye (ECD)-conjugated anti-CD19, vioblue-conjugated anti-lgD, PCy7-conjugated anti-CD11c, APC-conjugated anti-CD95, FITC-conjugated antiCD80, APC-conjugated anti-CXCR5, PCy7-conjugated anti-CD38, PE-conjugated anti-CD73, PE-conjugated anti-FCRL3 and anti-FCRL5. T-bet intracellular staining was performed using the PerFix -NC kit (Beckman Coulter) and (PB)-conjugated anti-T-bet antibodies; for T cells, PerCP-conjugated anti-CD4, PE-conjugated anti-CD25, and brillant violet 510-conjugated anti-CD127 (BioLegend). A live/dead discriminant dye was used in accordance with the manufacturer's instructions (Invitrogen). Cells cultured during $72 \mathrm{~h}$ were stained for cell surface markers and then permeabilized with Cytofix/Cytoperm buffer (BD PharMingen) and stained with FITC-conjugated anti-IFNy (BD PharMingen), PE-conjugated anti-TNFa, and Alexa Fluor 647-conjugated anti-IL-17A (eBioscience), or with APC-conjugated anti-FoxP3. FACS analyses were performed on a Navios flow cytometer using Kaluza analysis software (Beckman Coulter).

\section{Recombinant $F c$ antigens}

To produce recombinant Fc proteins, synthetic genes coding for the human IgK leader peptide followed by the $\lg \mathrm{H}$ hinge $(\mathrm{H})$ region, the $\lg$ constant domain $2\left(\mathrm{C}_{\mathrm{H}} 2\right.$, with a Cys $103 \mathrm{Ser}$ mutation) and $3\left(\mathrm{C}_{\mathrm{H}} 3\right)$ of human $\lg \mathrm{G} 1$ and $\lg \mathrm{G} 3$ were cloned into pcDNA ${ }^{\mathrm{TM}} 3.1 / \mathrm{Zeo}^{(+)}$ 
expression vector (Thermo Fisher Scientific). To generate swapped IgG1-G3 molecules, the sequences encoding the $\mathrm{H}-\mathrm{C}_{\mathrm{H}} 2$ and $\mathrm{C}_{\mathrm{H}} 3$ domains of $\lg \mathrm{G} 1$ and $\lg \mathrm{G} 3$ were interchanged in the respective synthetic DNA constructs. The N297A mutation was introduced by directed-site mutagenesis (QuikChange Site-Directed Mutagenesis Kit; Stratagene). All recombinant Fc were produced by transfection of FreeStyle ${ }^{\mathrm{TM}} 293-\mathrm{F}$ cells using the PEI method as previously described (18), and purified using protein G sepharose 4 fast flow beads (GE Healthcare). The Fc peptides library consisted of 8 amino acids-overlapping 20-mer peptides ( $n=23$; GenScript HK Limited) encompassing the entire lgG1 Fc region.

\section{Single B-cell FACS sorting and expression-cloning of antibodies}

PBMCs were stained as described above, and single AtM were sorted into 96-well PCR plates using a FACS Aria III sorter (Becton Dickinson) as previously described (19,20). Single-cell cDNA synthesis using SuperScript III reverse transcriptase (Fisher Scientific) followed by nested-PCR amplifications, sequencing and gene analyses were performed as previously described $(19,20)$. Ig $\mathrm{H}$ mutations selection strengths were determined using the BASELINE program (http://selection.med.yale.edu/baseline/) $(21,22)$. The IgM- and IgM Fab-expression vectors ( $\lg \mu$ and $\lg \mu-F a b$, respectively) were generated from the original IgG1-expression vector (20) by substituting the DNA sequence coding for the constant region of IgG1 by the one of the $\operatorname{lgM~CH} 1$ followed by an hexahistine tag or of the full $\operatorname{lgM}$ (synthetic DNA fragment, GenScript HK Limited) $(18,20)$. Purified digested PCR products were cloned into expressing vectors, and then used to co-transfect FreeStyle ${ }^{\mathrm{TM}} 293-\mathrm{F}$ cells as previously described(18),(19,20,23). For recombinant IgM production, the co-transfection of Expi293 cells with $\operatorname{lgM}$ and $\operatorname{lgL}(1 \mu \mathrm{g} / \mathrm{ml})$ and and $\mathrm{J}$-chain $(2.5 \mu \mathrm{g} / \mathrm{ml})$ expression vectors was performed using the Expi293 expression system (ThermoFisher Scientific). Culture supernatants were harvested 5-days post-transfection and concentrated by centrifugation cycles using Vivacell 100 ultrafiltration units (Sartorius). IgM concentration was determined by ELISA as described previously for $\lg G$ (18). Human IgG antibodies and Fab fragments were purified by affinity chromatography using protein $\mathrm{G}$ sepharose 4 fast flow and Ni sepharose excel beads (GE 
Healthcare), respectively. Antibody concentrations were determined using the NanoDrop 2000 instrument (Thermo Fisher Scientific).

\section{ELISAS}

Polyreactivity and HEp-2 ELISAs were performed as previously described (24). For Fc binding experiments, high-binding 96-well ELISA plates (Costar) were coated overnight with $15 \mu \mathrm{g} / \mathrm{well}$ of purified recombinant human IgG Fc fragments. After washings with $0.05 \%$ Tween-PBS (PBST), plates were blocked $2 \mathrm{~h}$ with $2 \%$ BSA, 1mM EDTA, PBST (Blocking buffer). After washings, coated plates were incubated $2 \mathrm{~h}$ with antibodies and seven consecutive 1:2 dilutions in PBS. After washings, the plates were revealed by incubation for $1 \mathrm{~h}$ with HRPconjugated goat anti-human Kappa light chain (1:10,000; Bethyl laboratories), and by adding $100 \mu \mathrm{l}$ of HRP chromogenic substrate (ABTS solution, Euromedex) after washing steps. For competition experiments, Fc-coated plates were blocked for $2 \mathrm{~h}$, washed and then incubated for $2 \mathrm{~h}$ with recombinant IgM in 1:2 serially diluted solutions of purified protein A (Sigma). Plates were developed as described above to test the binding of Fabs to IgG1 Fc, plates were coated overnight with $0.5 \mu \mathrm{g} /$ well of purified Fabs in PBS. Plates were then washed, blocked and incubated for $2 \mathrm{~h}$ with purified Fc at $50 \mu \mathrm{g} / \mathrm{ml}$ and seven consecutive 1:2 dilutions in PBS. Plates were revealed as previously described (24). IgG and IgM reactivity to $\lg G 1 \mathrm{Fc}$ peptides was tested as previously described (25). For HCV binding experiments, antibodies were tested using the ELISA Kit for Hepatitis C Virus (Amsbio).

\section{Immunoblotting}

Purified human Fc fragments were separated by SDS-PAGE with a NuPAGE® 4-12\% Bis-Tris Gel (Invitrogen), and electrotransferred onto nitrocellulose membranes. The filters were then saturated for $2 \mathrm{~h}$ in PBS-0.05\% Tween 20 (PBST)-5\% dry milk (blocking buffer), and incubated for $2 \mathrm{~h}$ with antibodies (at $30 \mu \mathrm{g} / \mathrm{ml}$ ) in blocking buffer. After washing with PBST, filters were incubated for $1 \mathrm{~h}$ with 1/5,000-diluted peroxydase-conjugated goat anti-human Kappa light chain (Jackson ImmunoResearch) in blocking buffer. After washings, filters were revealed by 
chemiluminescence reaction (ECL Prime, GE Healthcare), and images were acquired using a G:Box imaging system (Ozyme).

\section{Indirect immunofluorescence assay}

Recombinant antibodies (150 $\mathrm{g} / \mathrm{ml}$ ), and control antibodies (mGO53 (19), ED38 (26), and internal controls in the kit) were analyzed by indirect immunofluorescence assay on HEp-2 cells (ANA AeskruSlides, Ingen) using the fluorescence microscope Axio Imager 2 (Zeiss) as previously described (24).

\section{Gene expression profile analysis}

RNA was extracted from $10^{5}-10^{6}$ batch-sorted AtM stimulated or not with CpG for $72 \mathrm{~h}$, and using the NucleoSpin RNA II kit (Macherey-Nagel). The quality of the purified RNA was assessed with a 2100 Bioanalyzer (Agilent). Using the Illumina TotalPrep RNA Amplification Kit (Applied Biosystems), 100 ng RNA was amplified and labeled to produce cDNA. Labeled cDNA was hybridized on whole human genome chips (Human HT-12 Expression BeadChip Kit; Illumina). Data derived from three donors were normalized using BeadStudio and bioinformatics analysis was performed using GeneSpring GX 7.3 (Agilent). Probes with a signal $<20$ were excluded. Differential gene expression was defined according to the following criteria: Among the 48614 probes Set, 1664 probes set were differentially regulated according to an paired-test with $p<0.05$ and a false discovery rate (Benjamini Hochberg) $p<0.05$. We then selected the 251 probes set (=219 genes) with an absolute Fold Change of 2 . Functional enrichment and Network analysis were performed with Ingenuity Pathway Analysis IPA® (QIAGEN). For functional analysis, we selected function according to the $P$ values and the Zscore to improve biological relevance.

\section{Statistics}

Analyses were performed using GraphPad Prism 6.0 software (Graph-Pad Software). Except where indicated otherwise, values were expressed as mean \pm standard deviation (SD). 
Categorical variables were compared using the Fisher's exact or Chi2 tests, and continuous variables were compared using the two-tailed Mann-Whitney test. Multiple comparisons with more than two groups were performed using the Kruskal-Wallis test with $p$-values adjusted by the Bonferroni test (Dunn's method). 


\section{Results}

\section{Tbet ${ }^{+} C D 11 \mathrm{C}^{+} \mathrm{CD27}{ }^{+} \mathrm{CD} 21^{-}$atypical memory $\mathrm{B}$-cell expansions in $\mathrm{HCV}-\mathrm{CV}$}

Expansions of $C D 27^{+} \operatorname{lgM}{ }^{+} C D 21^{\text {low/- }} \mathrm{B}$ cells $($ AtM) were previously identified in $\operatorname{HCV}-\mathrm{CV}(11,12)$. The HCV-CV patients examined here (Table 1), also displayed an increased frequency of AtM cells $\left(\mathrm{CD} 27^{+} \mathrm{CD} 21^{-}\right.$B cells $)$compared to HCV patients without CV $[28 \%( \pm 4.9)$ vs $8.3 \%( \pm 1.9)$, $\mathrm{p}=0.008]$, and healthy donors $(\mathrm{HD})[2.8 \%( \pm 0.2), \mathrm{p}=0.001]$ (Figure $1 \mathrm{~A}, \mathrm{p}$-value $=0.0005) . \mathrm{A}$ significant decrease in AtM frequency was also observed [47( \pm 5$)$ vs 21( \pm 5$), p=0.015]$ after CV remission following 12 weeks of $\mathrm{HCV}$ therapy (DAA therapy) (Figure 1B). Although the frequency of AtM cells decreased, no significant change in AtM surface markers expression was observed following DAA therapy (Supplementary Figure 1). Tbet positive CD19+ B cells were mainly AtM subpopulation upon staining with CD27 and CD21 in HCV-CV patients but not in HCV controls and HD (Figure 1C, p-value= 0.0003$)[(49 \%( \pm 5.8)$ vs $21 \%( \pm 1.15)$ and $16 \%( \pm 5.8)]$. Thet positive CD19+ B cells exhibited a differential expression of surface molecules involved in T cell-B cell interactions as compared to "classical" CD27+CD21+ resting memory (RM) B cells (Figures 1D-E). HCV-CV AtM showed a significant higher expression of CD11c [1.6 $( \pm 0.2)$ vs 0.91 $( \pm 0.07), p=0.01]$, CD95 [2.8( \pm 0.2$)$ vs $2( \pm 0.2), p=0.04]$ and FCRL5 $[1.17( \pm 0.2)$ vs $0.55( \pm 0.18), p=0.01]$ and a decreased expression of CD73 [0.28( \pm 0.05$)$ vs $0.59( \pm 0.08), p=0.003]$ and CXCR5 [18( \pm 1$)$ vs 29( \pm 2$), \mathrm{p}=0.003]$ compared to RM B cells. CD80 and FCRL3 expression tended to be higher in AtM compared to RM and CD38 expression was decreased in AtM compared to RM (Figure 1D-E). Thus, AtM in HCV-CV share common phenotypic features with AtM subsets described in other chronic infections, autoimmune diseases and healthy individuals (27-29). We further compared the expression of these surface molecules on AtM and RM subpopulations between HCV-CV, HCV controls and HD. We found higher CD95, CD11C and CXCR5 expression in AtM and RM in HCV-CV patients compared to HCV controls and HD $[(\operatorname{AtM})(2.8( \pm 0.2)$ vs $1.2( \pm 0.5), \mathrm{p}=0.03$ vs 1.4(0.1), $\mathrm{p}=0.007$; $1.6( \pm 0.2)$ vs $0.7( \pm 0.05), \mathrm{p}=0.004$ vs $0.9( \pm 0.2) ; 18( \pm 2)$ vs $6( \pm 0.7), \mathrm{p}=0.009$ vs $5( \pm 0.8), \mathrm{p}=0.02)$ (RM) $2( \pm 0.2)$ vs $0.8( \pm 0.3), \mathrm{p}=0.02$ vs $0.6( \pm 0.08) \mathrm{p}=0.005 ; 0.9( \pm 0.07)$ vs $0.4( \pm 0.02), \mathrm{p}=0.004)$ vs $0.5( \pm 0.09), \mathrm{p}=0.03 ; 29( \pm 1.3)$ vs $11( \pm 2), \mathrm{p}=0.005$ vs $12( \pm 1.8), \mathrm{p}=0.005)]$. CD80 expression 
in HCV-CV patients was significantly lower in AtM and RM as compared to HCV controls and $\mathrm{HD}(\operatorname{AtM} 0.9( \pm 0.09)$ vs 1.4( \pm 0.007$), \mathrm{p}=0.03$ vs 1.9( \pm 0.2$), \mathrm{p}=0.007 ; \mathrm{RM} 0.7( \pm 0.05)$ vs $1.2( \pm 0.2)$, $\mathrm{p}=0.02$ vs $1.1( \pm 0.03), \mathrm{p}=0.002$. We found no difference in the expression of CD73 and CD38 between AtM and RM subpopulation in HCV-CV, HCV controls and HD (Supplementary Figure 2). Respective p-values for AtM CD95, RM CD95, AtM CD11c, RM CD11c, AtM CD73, RM CD73, AtM CD38, RM CD38, AtM CXCR5, RM CXCR5, AtM CD80 and RM CD80 were 0.007, $0.004,0.011,0.004,0.28,0.39,0.67,0.94,0.007,0.001,0.005,0.006$ (Supplementary Figure 2).

\section{TLR9 signaling in HCV-CV AtM promote pro-inflammatory Th1 response}

TLR9 stimulation can lead to B-cell dysfunction in autoimmune diseases $(30,31)$. Stimulation with TLR9 ligand (i.e., CpG) of sorted AtM from active HCV-CV patients enhanced their secretion of TNFa (0.4\% vs 8.8\%, $p=0.0003)$, but not of IL2, IL6 and IL10 (Figure 2A, p-value= 0.75). Enhanced secretion of TNFa upon CpG simulation was significantly higher in AtM of HCV-CV patients compared to HCV controls and HD $(8.8( \pm 1)$ vs $3.5( \pm 1), p=0.01$ vs $3.5( \pm 0.5)$, $\mathrm{p}=0.02)$ (Figure $2 \mathrm{~A})$. Stimulation by $\mathrm{CpG}$ also increased the proliferation of AtM $(2.5 \% \mathrm{vs}$ $39.5 \%, p=0.001$ ) (Figure $2 \mathrm{~B}, \mathrm{p}$-value $=0.027$ ), and the production of $\lg \mathrm{M}$ with reactivity to human IgG1 Fc (Figure 2C). We next analyzed the function of AtM cells by studying the expression of CD69, CD25, CD95 and CD44. CD69, CD25 and CD95 expression on AtM cells were significantly increased after stimulation by $\mathrm{CpG}$ in HCV-CV patients and HCV controls (5.6( \pm 0.7$)$ vs 55( \pm 3.6$), p=0.0006,14( \pm 2)$ vs $58( \pm 2) \mathrm{p}=0.02 ; 9( \pm 2)$ vs $44( \pm 10) \mathrm{p}=0.002,4( \pm 1)$ vs $42( \pm 5) p=0.02 ; 19.5( \pm 0.2)$ vs $61( \pm 9), p=0.04,6.9( \pm 1.3)$ vs $23( \pm 0.6), p=0.02$ (Figure $2 \mathrm{D}$, respective $p$-values for the expression of CD69, CD25, CD95 and CD44 were 0.43, 0.72, 0.86 and 0.95). Stimulation of AtM cells with CpG has no significant impact on CD44 expression in HCV-CV patients (Figure 2D). Th1 cells have been involved in the pathogenesis of HCV-CV $(9,32)$. We therefore evaluated whether AtM can control the release of pro-inflammatory cytokines by $\mathrm{CD}^{+}{ }^{+} \mathrm{CD} 25-$ effector T cells (Teff) in HCV-CV patients. Sorted AtM stimulated or not with $\mathrm{CpG}$ were cocultured with autologous $\mathrm{CD} 4^{+} \mathrm{CD} 25^{-} \mathrm{T}$ cells. The presence of AtM 
stimulated with $\mathrm{CpG}$ cocultured with autologous $\mathrm{CD}^{+}{ }^{+} \mathrm{CD} 25^{-} \mathrm{T}$ cells tend to increase IFNy (Figure 3A, p-value $=0.028)$ and TNFa (Figure-3B, p-value $=0.013)$ production by autologous $\mathrm{CD}^{+}{ }^{+} \mathrm{CD} 25^{-} \mathrm{T}$ cells, but did not significantly affect IL17A expression (Figure $3 \mathrm{C}$, $\mathrm{p}$-value $=0.73$ ). Functional defects of regulatory T cells (Tregs) contribute to HCV-CV-associated autoimmune manifestations $(6,33,34)$. However, it is still unclear whether clonally expanded AtM contribute to the perturbations in T-cell homeostasis in HCV-CV. CpG-stimulated AtM were cocultured with autologous Teff or Tregs stimulated with anti-CD3/CD28. CpG-stimulated AtM reduced Tregs proliferation ( $83 \%$ vs $44 \%, p=0.036)$, and increased Teff proliferation $(81 \%$ vs $89 \%$, $p=0.01$ ) (Figures 3D-E). Thus, TLR9 signaling in AtM promotes the proliferation and secretion of IFNy and TNFa but not IL17A by effector T cells, and reduces the proliferation of regulatory T cells in HCV-CV. The addition of anti-TNFa in the coculture decreased significantly IFNy and TNFa secretion by effector T cells but did not impact Treg proliferation (Figure 3). No significant changes in the expression of functional markers of Tregs (CTLA4, ICOS and PD1) were observed when stimulated AtM were cocultured with Tregs (data not shown).

\section{Stimulated HCV-CV AtM harbor a specific TNFa-centered transcriptional profile}

Transcriptional profiling of HCV-CV AtM previously revealed an association with molecular pathways involved in anergy, apoptosis, and dampened activation of $B$ cells $(11,13)$. To define gene signatures associated with the effect of TLR9 stimulation on AtM, we compared gene expression profiles of CpG-stimulated and unstimulated AtM (control) from HCV-CV patients (Figure 4). We identified a gene signature of 229 genes in total (210 up-regulated and 19 downregulated) in CpG-stimulated AtM compared to control (Figure 4A). Functional enrichment analysis in CpG-stimulated AtM revealed many up-regulated genes that are involved in B-and Th1-cell activation (Figure 4B). Among the top up-regulated genes, we found high expression of MIR155HG coding for miRNA-155, which influences BCR signaling and is highly expressed on activated B cells (35), and contribute to tolerance breakage when induced in B cells upon TLR9 signaling (30). Interestingly, the proinflammatory cytokine MIF driving Th1 response (36) was also highly expressed in CpG-stimulated AtM. We then focused on the molecular networks 
showing the most induced genes as a group in CpG-stimulated AtM (Figure 4C). The gene content of this transcriptional module was enriched in genes encoding proteins involved in B cell activation and differentiation, signal transduction and in T-cell costimulation, such as TNFa, Interferon regulatory factor-4 (IRF4), BLIMP1 (PRDM1), and STAT3 genes (Figure 4C). Among the top genes down-regulated, we identified FAIM3 that encodes an IgM Fc receptor, and which may serve as an uptake receptor for lgM-opsonized antigens by B cells (37). HVCN1 (Hydrogen Voltage Gated Channel 1) coding for a voltage-gated proton channel and C8orf13BLK (src family tyrosine kinase) were also down-regulated in CpG-stimulated AtM. Interestingly, HVCN1-deficient mice exhibit autoimmune phenotypes including splenomegaly, nephritis, and autoantibody production (38). Polymorphisms of C8orf13-BLK are associated with autoimmune diseases (39-41). Altogether, these data suggest that the activation of AtM through TLR9 signaling could lead to a Th1 pro-inflammatory state, which could facilitate tolerance breakage in HCV infection.

\section{AtM display antigen-driven maturation features}

To characterize the antibody repertoire and reactivity of AtM, we isolated single circulating blood AtM from three donors (Figure 5A), amplified and sequenced their heavy- and light-chain variable domain ( $\lg \mathrm{H}$ and $\mathrm{lg} \mathrm{L}$, respectively) genes. We found that most if not all captured AtM belong to unique clonal families (96 to 100\%) (Figure 5B), characterized by various degrees of clonal diversity depending on the donor (Figure $5 \mathrm{C}$ ). Clonally expanded B cells in donor pt1 expressed IgMs encoded by $V_{H} 1-69 / D_{H} 3-10 / J_{H} 4$ and $V_{\kappa} 3-20 / J_{\kappa} 2$ rearrangements (Figure 5D). Interestingly, pt2 and pt3 donors showed clonal expansions of AtM with very similar recombined $\lg \mathrm{H}$ and $\lg \mathrm{L}$. Both used $\mathrm{V}_{\mathrm{H}} 3-7$ and $\mathrm{J}_{\mathrm{H}} 3$ genes with a $D_{H} 3-10$ or $D_{H} 3-22$ segment, and $V_{\kappa} 3-15$ and $J_{\kappa} 1$ genes (Figure $5 D$ ). AtM antibodies displayed moderate to relatively high levels of somatic mutations in $\mathrm{IgH}$ and $\mathrm{lgL}$ variable genes (Figure $5 \mathrm{E}$ ). Somatic mutations showed a strong selection of replacement mutations in CDRs compared to FRWs (Figure 5F), suggesting that anergic AtM were shaped following an antigen-driven affinity maturation process. 


\section{AtM antibodies are rheumatoid factors lacking $\mathrm{HCV}$ reactivity}

To identify the antigen specificities of HCV-CV AtM antibodies, we produced as recombinant monoclonal antibodies representative members of each clonal expansion (Figure 5C). IgM expressed by clonally expanded anergic AtM have been shown to exert rheumatoid factor activity (16). All recombinant IgM antibodies recognized the human IgG1 Fc fragment (IgG1Fc) (Figure 6A), confirming their RF activity. Fab fragments of parental IgM but not $\lg G$ counterparts bound to $\lg \mathrm{G} 1-\mathrm{Fc}$, which may be explain by self-competition of RF binding site in complex with its own Fc when expressed as a full $\operatorname{lgG}$ molecule. They also reacted against IgG1-Fc by immunoblotting (Figure 6B) but not against any of the overlapping peptides covering the entire Fc region (Figure $6 \mathrm{C}$ ), suggesting that the epitopes recognized by AtM antibodies are conformational. Moreover, we assessed whether unresponsive RF-expressing AtM display auto- and poly-reactive properties. ELISA binding experiments showed that IgG and IgM RF antibodies exhibit neither polyreactivity nor self-reactivity against HEp-2 cell antigens (Figure 6D). Cross-reactivity of RF antibodies against HCV antigens has been evocated (42-44), but never been formally demonstrated. ELISA binding analysis showed that none of the recombinant antibodies recognized HCV NS3-5, Core, and E2 proteins (Figure $6 \mathrm{E})$.

\section{AtM antibodies recognize distinct IgG Fc epitopes}

To define more precisely the epitopes targeted by AtM-derived RF, we first investigated the potential role of $\mathrm{Fc}$-associated $\mathrm{N}$-glycans. Antibody binding analyses showed that $\operatorname{lgM}$ reactivity was not affected by the absence of $\mathrm{N}$-glycans in position N297 (Figure 7A). Since the association of Staphylococcus aureus protein A with Fc protein was previously shown to interfere with HCV-associated RF reactivity (16), we next assayed the IgM binding to Fc in presence of purified protein A. Competition ELISA analyses indicated that protein A could block or decrease the Fc-binding by representative IgMs from pt1 and pt2 but not from pt3 (Figure 7B). Finally, we compared by ELISA, the IgM binding to $\lg G 1$, IgG3 and hybrid Fc molecules 
made of the $\mathrm{H}-\mathrm{CH} 2$ of $\lg \mathrm{G} 1$ followed by the $\mathrm{CH} 3$ of $\lg \mathrm{G} 3$, and vice et versa. Our results showed that 1-04 bound preferentially to $\lg \mathrm{G} 1$ and hybrid Fc proteins and also to a lesser extend to IgG3 (Figure 7C). The lower affinity variant 1-10 as well as 2-23 and 3-70 only reacted against the entire $\lg \mathrm{G} 1 \mathrm{Fc}$ and its $\mathrm{CH} 3$ domain on the corresponding hybrid molecule (Figure $7 \mathrm{C}$ ). Together, these data suggest that the RF expressed by the expanded clonal AtM target various epitopes on the human Fc (Figure 7D). 


\section{Discussion}

Immune dysregulation in HCV-CV involves expansions of anergic AtM believed to produce rheumatoid factor autoantibodies $(1,8,16)$. HCV-CV AtM have increased levels of molecules involved in T-B cell interactions including CD11C, CD80 and CD86/B7-2 (11,13). AtM with similar phenotypic features have also been identified in the context of chronic infections (4547), in autoimmune diseases $(15,48)$, and in healthy individuals $(27)$. We found here that AtM have higher expression of T-bet, CD11c, CD80, CD95, FCRL3, and FCRL5, and decreased CD73 and CXCR5 surface levels compared to resting memory B cells in HCV-CV $(13,49,50)$. Moreover, T-bet expression in AtM was enhanced in HCV-CV patients compared to HCV controls without CV. Interestingly, the expansion of AtM cells in HCV-CV patients decreased significantly after DAA therapy, whereas the expression of AtM surface markers remained unchanged. This is likely a consequence of the antigens removal, and cessation of chronic viral stimulation of autoreactive AtM following DAA therapy.

Human AtM may differ functionally depending on the context of chronic infections or autoimmunity. HIV- and malaria-associated AtM exhibit markedly reduced cytokine and antibody production capacity $(45,51,52)$, whereas AtM found in autoimmune diseases produce proinflammatory cytokines and autoantibodies (53-55). HCV-CV AtM resemble exhausted cells found in chronic inflammation, which are anergic and lack differentiation potential into antibody-secreting cells (15). However, TLR9 signaling in AtM could break this anergic state (56). While such signals would ordinarily trigger apoptosis, cognate T-cell help and cytokines such as IFNy and TNFa could promote autoantibody production (57). We showed here that stimulation of AtM by TLR9 ligand CpG drives their differentiation into rheumatoid factorproducing cells. We found that CpG-stimulated AtM display an enhanced TNFa secretion, which is likely responsible for the proliferation and secretion of IFNY and TNFa by effector T cells. The interplay between BCR, TLR9, and cytokines signaling in the generation of T-bet ${ }^{+}$ CD11 $\mathrm{C}^{+} \mathrm{B}$ cells have been recently unveiled (58). In mice, Plasmodium DNA-sensing through TLR9 along with IFN $\square \mathrm{R}$ have been shown to provide an essential synergizing signal for promoting AtM expansion and the subsequent development of autoimmune anemia (59). 
Activation of murine autoreactive $\mathrm{RF}^{+} \mathrm{B}$ cells by immune complexes requires the synergistic engagement of the BCR and MyD88-dependent TLR members (i.e., TLR7, TLR8 and TLR9) (60). These data suggest a critical link between innate and adaptive immune responses in the development of systemic autoimmune diseases particularly, when associated to chronic infections. Thus, consistent with our results, we hypothesize that TLR9 signaling could activate anergic RF-expressing AtM cells, which in turn would create a pro-inflammatory environment by favoring Th1 response. Analyses of the transcriptional program of CpG-activated HCV-CV AtM provided further evidences supporting this scenario. HCV-CV AtM previously revealed an association with molecular pathways involved in anergy, and dampened activation of $B$ cells via their BCR $(1,4)$. In contrast, CpG-stimulated AtM up-regulated many genes involved B-cell activation and T-B interactions, and centered on TNFa overexpression. TNF $\square$ activates STAT3, a key regulator of B cell proliferation and survival (61). Higher transcript expression for miRNA-155 and the heat shock proteins (HSP90B1, HSPD1, HSPE1), which are known to induce B cell activation and to disrupt immune tolerance (8-10), as well as IRF4 and BLIMP1 that promote immunoglobulins production (62), were also evidenced in activated AtM. Moreover, we identified a transcriptomic program in TLR-9-stimulated AtM driving T-B cell interactions (TNFa, IRF4, and STAT3) and Th1 pro-inflammatory immune response (MIF). Taken together, these data suggest that activation of AtM through TLR9 signaling lead to a subsequent RF production but also to a B cell-driven Th1 pro-inflammatory state.

AtM captured from HCV-CV were part of large single clonal expansions and showed clear evidences of antigen-driven maturation $(11,12,16)$. Atm-derived recombinant IgM antibodies displayed RF activity with increased binding to IgG Fc by avidity effects as shown elsewhere (16). Fc-binding was not due to polyreactivity, and was not associated with additional autoreactivity features. This contrasts with the frequent or predominant poly- and self-reactivity described for the AtM subsets expanded in other infectious and autoimmune diseases $(15,47,63,64)$. Interestingly, mapping of AtM RFs revealed the diversity of targeted epitopes on the Fc region, with no immunodominance towards a common unique epitope. This is reminiscent of the epitopic diversity characterizing RFs in rheumatoid arthritis (65), which 
probably use different types of interactions for Fc recognition $(66,67)$. The E2 subunit of the HCV envelope spike contains a $\square$-sandwich element sharing structural homology with immunoglobulin domains (68). A phenomenon of molecular mimicry between Ig folds of human IgGs and HCV envelope glycoproteins has been proposed to explain the development of RF in HCV-CV (42). However, we found that AtM RF IgMs do not cross-react with HCV antigens including the E2 moiety. In line with this, whether antibodies expressed by HCV-associated lymphoma cells, some of which exhibiting RF activity, truly recognize the E2 protein remains equivocal $(44,69,70)$. Thus, IgGs, possibly bound to viral antigens as immune complexes, are most likely the only culprit antigens driving the emergence of clonally-expanded B cells with RF activity in HCV-CV.

In conclusion, our results suggest a central role for TLR9 activation of AtM in breaking tolerance in HCV-CV patients. Importantly, we showed in HCV-CV that CpG-stimulated AtM, through the secretion of TNFa, have deleterious effects by stimulating proliferation and activation of effector Th1 cells, inhibiting Tregs proliferation and promoting the production of IgM with RF activity. RF molecules produced by AtM recognized distinct IgG-Fc epitopes and did not cross-reacted against HCV proteins, confirming that molecular mimicry between HCV and human IgG proteins is not the trigger of HCV-associated autoimmunity. 


\section{Acknowledgements}

We are grateful to all participants who consented to be part of this study. We thank Valentina Libri for her assistance with single cell sorting at the Center for Human Immunology $(\mathrm{ClH}$, Institut Pasteur). The authors also thank the UMR 8199 LIGAN-MP Genomics platform (Lille, France), which belongs to the "Federation de Recherche" 3508 Labex EGID (European Genomics Institute for Diabetes; ANR-10-LABX-46) and was supported by the ANR Equipex 2010 session (ANR-10-EQPX-07-01; “LIGAN-MP”). The LIGAN-PM Genomics platform (Lille, France) is also supported by the FEDER and the Region Nord-Pas-de-Calais-Picardie. This work was supported by the ANRS (CSS4 AO 2014-2). H.M. was supported by the G5 Institut Pasteur Program and the Milieu Intérieur Program (ANR-10-LABX-69-01). C.C. was supported by the Fondation pour la Recherche Médicale (FDM20140630463) and C.M. by "Année Recherche de l'Agence Régionale de Santé d'lle de France" (\#2016-11-52). 


\section{REFERENCES}

1. Cacoub P, Poynard T, Ghillani P, Charlotte F, Olivi M, Piette JC, et al. Extrahepatic manifestations of chronic hepatitis C. MULTIVIRC Group. Multidepartment Virus C. Arthritis Rheum. 1999;42:2204-2212.

2. Desbois AC, Cacoub P, Saadoun D. Cryoglobulinemia: An update in 2019. Jt. Bone Spine Rev. Rhum. 2019; Feb 4. pii: S1297-319X(19)30014-4.

3. Roccatello D, Saadoun D, Ramos-Casals M, Tzioufas AG, Fervenza FC, Cacoub P, et al. Cryoglobulinaemia. Nat. Rev. Dis. Primer. 2018;4:11.

4. Cacoub P, Renou C, Rosenthal E, Cohen P, Loury I, Loustaud-Ratti V, et al. Extrahepatic manifestations associated with hepatitis $C$ virus infection. A prospective multicenter study of 321 patients. The GERMIVIC. Groupe d'Etude et de Recherche en Medecine Interne et Maladies Infectieuses sur le Virus de l'Hepatite C. Medicine (Baltimore). 2000;79:4756.

5. Cacoub P, Comarmond C, Domont F, Savey L, Saadoun D. Cryoglobulinemia Vasculitis. Am. J. Med. 2015; 128(9):950-5.

6. Boyer O, Saadoun D, Abriol J, Dodille M, Piette J-C, Cacoub P, et al. CD4+CD25+ regulatory $\mathrm{T}$-cell deficiency in patients with hepatitis $\mathrm{C}$-mixed cryoglobulinemia vasculitis. Blood. 2004;103:3428-3430.

7. Lenzi M, Frisoni M, Mantovani V, Ricci P, Muratori L, Francesconi R, et al. Haplotype HLAB8-DR3 confers susceptibility to hepatitis $C$ virus-related mixed cryoglobulinemia. Blood. 1998;91:2062-2066.

8. Saadoun D, Landau DA, Calabrese LH, Cacoub PP. Hepatitis C-associated mixed cryoglobulinaemia: a crossroad between autoimmunity and lymphoproliferation. Rheumatol. Oxf. Engl. 2007;46:1234-1242.

9. Saadoun $D$, Boyer $O$, Trébeden-Nègre $H$, Limal $N$, Bon-Durand $V$, Andreu $M$, et al. Predominance of type 1 (Th1) cytokine production in the liver of patients with HCVassociated mixed cryoglobulinemia vasculitis. J. Hepatol. 2004;41:1031-1037.

10. Saadoun D, Bieche I, Maisonobe T, Asselah T, Laurendeau I, Piette JC, et al. Involvement of chemokines and type 1 cytokines in the pathogenesis of hepatitis $C$ virusassociated mixed cryoglobulinemia vasculitis neuropathy. Arthritis Rheum. 2005;52:2917-2925.

11. Terrier B, Joly F, Vazquez T, Benech P, Rosenzwajg M, Carpentier W, et al. Expansion of functionally anergic CD21-/low marginal zone-like B cell clones in hepatitis C virus infection-related autoimmunity. J. Immunol. Baltim. Md 1950. 2011;187:6550-6563.

12. Charles ED, Green RM, Marukian S, Talal AH, Lake-Bakaar GV, Jacobson IM, et al. Clonal expansion of immunoglobulin $\mathrm{M}+\mathrm{CD} 27+\mathrm{B}$ cells in $\mathrm{HCV}$-associated mixed cryoglobulinemia. Blood. 2008;111:1344-1356.

13. Charles ED, Brunetti C, Marukian S, Ritola KD, Talal AH, Marks K, et al. Clonal B cells in patients with hepatitis $C$ virus-associated mixed cryoglobulinemia contain an expanded anergic CD21low B-cell subset. Blood. 2011;117:5425-5437.

14. Duty JA, Szodoray P, Zheng N-Y, Koelsch KA, Zhang Q, Swiatkowski M, et al. Functional anergy in a subpopulation of naive $B$ cells from healthy humans that express autoreactive immunoglobulin receptors. J. Exp. Med. 2009;206:139-151.

15. Isnardi I, Ng Y-S, Menard L, Meyers G, Saadoun D, Srdanovic I, et al. Complement receptor 2/CD21 - human naive B cells contain mostly autoreactive unresponsive clones. Blood. 2010;115:5026-5036.

16. Charles ED, Orloff MIM, Nishiuchi E, Marukian S, Rice CM, Dustin LB. Somatic hypermutations confer rheumatoid factor activity in hepatitis $C$ virus-associated mixed cryoglobulinemia. Arthritis Rheum. 2013;65:2430-2440.

17. Comarmond C, Garrido M, Pol S, Desbois A-C, Costopoulos M, Le Garff-Tavernier M, et al. Direct-Acting Antiviral Therapy Restores Immune Tolerance to Patients With Hepatitis C Virus-Induced Cryoglobulinemia Vasculitis. Gastroenterology. 2017;152:20522062.e2. 
18. Lorin $\mathrm{V}$, Mouquet $\mathrm{H}$. Efficient generation of human $\lg \mathrm{A}$ monoclonal antibodies. J. Immunol. Methods. 2015;422:102-110.

19. Wardemann H, Yurasov S, Schaefer A, Young JW, Meffre E, Nussenzweig MC. Predominant autoantibody production by early human B cell precursors. Science. 2003;301:1374-1377.

20. Tiller T, Meffre E, Yurasov S, Tsuiji M, Nussenzweig MC, Wardemann H. Efficient generation of monoclonal antibodies from single human $B$ cells by single cell RT-PCR and expression vector cloning. J. Immunol. Methods. 2008;329:112-124.

21. Uduman M, Yaari G, Hershberg U, Stern JA, Shlomchik MJ, Kleinstein SH. Detecting selection in immunoglobulin sequences. Nucleic Acids Res. 2011;39:W499-504.

22. Yaari G, Uduman M, Kleinstein SH. Quantifying selection in high-throughput Immunoglobulin sequencing data sets. Nucleic Acids Res. 2012;40:e134.

23. Mouquet H, Scharf L, Euler Z, Liu Y, Eden C, Scheid JF, et al. Complex-type N-glycan recognition by potent broadly neutralizing HIV antibodies. Proc. Natl. Acad. Sci. U. S. A. 2012;109:E3268-3277.

24. Prigent J, Lorin V, Kök A, Hieu T, Bourgeau S, Mouquet H. Scarcity of autoreactive human blood $\lg \mathrm{A}(+)$ memory B cells. Eur. J. Immunol. 2016; 46(10):2340-2351.

25. Mouquet $H$, Farci $S$, Joly $P$, Maillère $B$, Leblond $J$, Drouot $L$, et al. A truncated alternative spliced isoform of human desmoglein 1 contains a specific $T$ cell epitope binding to the pemphigus foliaceus-associated HLA class II DRbeta1*0102 molecule. J. Immunol. Baltim. Md 1950. 2006;177:6517-6526.

26. Meffre E, Schaefer A, Wardemann H, Wilson P, Davis E, Nussenzweig MC. Surrogate light chain expressing human peripheral B cells produce self-reactive antibodies. J. Exp. Med. 2004:199:145-150.

27. Lau D, Lan LY-L, Andrews SF, Henry C, Rojas KT, Neu KE, et al. Low CD21 expression defines a population of recent germinal center graduates primed for plasma cell differentiation. Sci. Immunol. 2017; 2(7). pii: eaai8153.

28. Karnell JL, Kumar V, Wang J, Wang S, Voynova E, Ettinger R. Role of CD11C+ T-bet+ B cells in human health and disease. Cell. Immunol. 2017;321:40-45.

29. Portugal S, Obeng-Adjei N, Moir S, Crompton PD, Pierce SK. Atypical memory B cells in human chronic infectious diseases: An interim report. Cell. Immunol. 2017;321:18-25.

30. Liu F, Fan H, Ren D, Dong G, Hu E, Ji J, et al. TLR9-induced miR-155 and Ets-1 decrease expression of CD1d on B cells in SLE. Eur. J. Immunol. 2015;45:1934-1945.

31. Simchoni N, Cunningham-Rundles C. TLR7- and TLR9-responsive human B cells share phenotypic and genetic characteristics. J. Immunol. Baltim. Md 1950. 2015;194:30353044.

32. Kong F, Zhang W, Feng B, Zhang H, Rao H, Wang J, et al. Abnormal CD4 + T helper (Th) 1 cells and activated memory B cells are associated with type III asymptomatic mixed cryoglobulinemia in HCV infection. Virol. J. 2015;12:100.

33. Saadoun D, Rosenzwajg M, Joly F, Six A, Carrat F, Thibault V, et al. Regulatory T-cell responses to low-dose interleukin-2 in $\mathrm{HCV}$-induced vasculitis. N. Engl. J. Med. 2011;365:2067-2077.

34. Landau D-A, Rosenzwajg $M$, Saadoun $D$, Trébeden-Negre $H$, Klatzmann $D$, Cacoub $P$. Correlation of clinical and virologic responses to antiviral treatment and regulatory $T$ cell evolution in patients with hepatitis $\mathrm{C}$ virus-induced mixed cryoglobulinemia vasculitis. Arthritis Rheum. 2008;58:2897-2907.

35. Elton TS, Selemon H, Elton SM, Parinandi NL. Regulation of the MIR155 host gene in physiological and pathological processes. Gene. 2013;532:1-12.

36. Sánchez-Zamora YI, Juarez-Avelar I, Vazquez-Mendoza A, Hiriart M, Rodriguez-Sosa M. Altered Macrophage and Dendritic Cell Response in Mif-/- Mice Reveals a Role of Mif for Inflammatory-Th1 Response in Type 1 Diabetes. J. Diabetes Res. 2016;2016:7053963.

37. Shima H, Takatsu H, Fukuda S, Ohmae M, Hase K, Kubagawa H, et al. Identification of TOSO/FAIM3 as an Fc receptor for IgM. Int. Immunol. 2010;22:149-156.

38. Sasaki M, Tojo A, Okochi Y, Miyawaki N, Kamimura D, Yamaguchi A, et al. Autoimmune disorder phenotypes in Hvcn1-deficient mice. Biochem. J. 2013;450:295-301. 
39. Hom G, Graham RR, Modrek B, Taylor KE, Ortmann W, Garnier S, et al. Association of systemic lupus erythematosus with C8orf13-BLK and ITGAM-ITGAX. N. Engl. J. Med. 2008;358:900-909.

40. Gourh P, Agarwal SK, Martin E, Divecha D, Rueda B, Bunting H, et al. Association of the C8orf13-BLK region with systemic sclerosis in North-American and European populations. J. Autoimmun. 2010;34:155-162.

41. Torres O, Palomino-Morales R, Vazquez-Rodriguez TR, Castañeda S, Morado IC, Miranda-Filloy JA, et al. Role of the C8orf13-BLK region in biopsy-proven giant cell arteritis. Hum. Immunol. 2010;71:525-529.

42. De Re V, Sansonno D, Simula MP, Caggiari L, Gasparotto D, Fabris M, et al. HCV-NS3 and IgG-Fc crossreactive IgM in patients with type II mixed cryoglobulinemia and B-cell clonal proliferations. Leukemia. 2006;20:1145-1154.

43. Hu Y-W, Rocheleau L, Larke B, Chui L, Lee B, Ma M, et al. Immunoglobulin mimicry by Hepatitis C Virus envelope protein E2. Virology. 2005;332:538-549.

44. Ng PP, Kuo C-C, Wang S, Einav S, Arcaini L, Paulli M, et al. B-cell receptors expressed by lymphomas of hepatitis $\mathrm{C}$ virus $(\mathrm{HCV})$-infected patients rarely react with the viral proteins. Blood. 2014;123:1512-1515.

45. Moir S, Ho J, Malaspina A, Wang W, DiPoto AC, O'Shea MA, et al. Evidence for HIVassociated $B$ cell exhaustion in a dysfunctional memory $B$ cell compartment in HIVinfected viremic individuals. J. Exp. Med. 2008;205:1797-1805.

46. Kardava L, Moir S, Shah N, Wang W, Wilson R, Buckner CM, et al. Abnormal B cell memory subsets dominate HIV-specific responses in infected individuals. J. Clin. Invest. 2014;124:3252-3262.

47. Muellenbeck MF, Ueberheide B, Amulic B, Epp A, Fenyo D, Busse CE, et al. Atypical and classical memory $B$ cells produce Plasmodium falciparum neutralizing antibodies. J. Exp. Med. 2013;210:389-399.

48. Nicholas MW, Dooley MA, Hogan SL, Anolik J, Looney J, Sanz I, et al. A novel subset of memory $B$ cells is enriched in autoreactivity and correlates with adverse outcomes in SLE. Clin. Immunol. Orlando Fla. 2008;126:189-201.

49. Terrier B, Nagata S, Ise T, Rosenzwajg M, Pastan I, Klatzmann D, et al. CD21(-/low) marginal zone B cells highly express Fc receptor-like 5 protein and are killed by anti-Fc receptor-like 5 immunotoxins in hepatitis $C$ virus-associated mixed cryoglobulinemia vasculitis. Arthritis Rheumatol. Hoboken NJ. 2014;66:433-443.

50. Chang L-Y, Li Y, Kaplan DE. Hepatitis $C$ viraemia reversibly maintains subset of antigenspecific T-bet+ tissue-like memory B cells. J. Viral Hepat. 2017;24:389-396.

51. Portugal S, Tipton CM, Sohn H, Kone Y, Wang J, Li S, et al. Malaria-associated atypical memory B cells exhibit markedly reduced B cell receptor signaling and effector function. eLife. 2015;4.

52. Kardava L, Moir S, Wang W, Ho J, Buckner CM, Posada JG, et al. Attenuation of HIVassociated human $B$ cell exhaustion by siRNA downregulation of inhibitory receptors. J. Clin. Invest. 2011;121:2614-2624.

53. Wang Z, Wang Z, Wang J, Diao Y, Qian X, Zhu N. T-bet-Expressing B Cells Are Positively Associated with Crohn's Disease Activity and Support Th1 Inflammation. DNA Cell Biol. 2016;35:628-635.

54. Rakhmanov M, Keller B, Gutenberger S, Foerster C, Hoenig M, Driessen G, et al. Circulating CD21low $B$ cells in common variable immunodeficiency resemble tissue homing, innate-like B cells. Proc. Natl. Acad. Sci. U. S. A. 2009;106:13451-13456.

55. Claes N, Fraussen J, Vanheusden M, Hellings N, Stinissen P, Van Wijmeersch B, et al. Age-Associated B Cells with Proinflammatory Characteristics Are Expanded in a Proportion of Multiple Sclerosis Patients. J. Immunol. Baltim. Md 1950. 2016;197:45764583.

56. Buchta CM, Bishop GA. Toll-like receptors and B cells: functions and mechanisms. Immunol. Res. 2014;59:12-22. 
57. Sindhava VJ, Oropallo MA, Moody K, Naradikian M, Higdon LE, Zhou L, et al. A TLR9dependent checkpoint governs $B$ cell responses to DNA-containing antigens. J. Clin. Invest. 2017; 127:1651-1663.

58. Naradikian MS, Myles A, Beiting DP, Roberts KJ, Dawson L, Herati RS, et al. Cutting Edge: IL-4, IL-21, and IFN-y Interact To Govern T-bet and CD11c Expression in TLRActivated B Cells. J. Immunol. Baltim. Md 1950. 2016;197:1023-1028.

59. Rivera-Correa J, Guthmiller JJ, Vijay R, Fernandez-Arias C, Pardo-Ruge MA, Gonzalez $\mathrm{S}$, et al. Plasmodium DNA-mediated TLR9 activation of T-bet+ B cells contributes to autoimmune anaemia during malaria. Nat. Commun. 2017;8:1282.

60. Leadbetter EA, Rifkin IR, Hohlbaum AM, Beaudette BC, Shlomchik MJ, MarshakRothstein A. Chromatin-IgG complexes activate B cells by dual engagement of IgM and Toll-like receptors. Nature. 2002;416:603-607.

61. Kortylewski M, Kujawski M, Wang T, Wei S, Zhang S, Pilon-Thomas S, et al. Inhibiting Stat3 signaling in the hematopoietic system elicits multicomponent antitumor immunity. Nat. Med. 2005;11:1314-1321.

62. Oracki SA, Walker JA, Hibbs ML, Corcoran LM, Tarlinton DM. Plasma cell development and survival. Immunol. Rev. 2010;237:140-159.

63. Saadoun D, Terrier B, Bannock J, Vazquez T, Massad C, Kang I, et al. Expansion of autoreactive unresponsive CD21-/low B cells in Sjögren's syndrome-associated lymphoproliferation. Arthritis Rheum. 2013;65:1085-1096.

64. Meffre E, Louie A, Bannock J, Kim LJY, Ho J, Frear CC, et al. Maturational characteristics of HIV-specific antibodies in viremic individuals. JCI Insight. 2016; 1(3).

65. Bonagura VR, Agostino N, Børretzen M, Thompson KM, Natvig JB, Morrison SL. Mapping IgG epitopes bound by rheumatoid factors from immunized controls identifies diseasespecific rheumatoid factors produced by patients with rheumatoid arthritis. J. Immunol. Baltim. Md 1950. 1998;160:2496-2505.

66. Corper AL, Sohi MK, Bonagura VR, Steinitz M, Jefferis R, Feinstein A, et al. Structure of human IgM rheumatoid factor Fab bound to its autoantigen IgG Fc reveals a novel topology of antibody-antigen interaction. Nat. Struct. Biol. 1997;4:374-381.

67. Duquerroy S, Stura EA, Bressanelli S, Fabiane SM, Vaney MC, Beale D, et al. Crystal structure of a human autoimmune complex between IgM rheumatoid factor RF61 and IgG1 Fc reveals a novel epitope and evidence for affinity maturation. J. Mol. Biol. 2007;368:1321-1331.

68. Kong L, Giang E, Nieusma T, Kadam RU, Cogburn KE, Hua Y, et al. Hepatitis C virus E2 envelope glycoprotein core structure. Science. 2013;342:1090-1094.

69. Chan $\mathrm{CH}$, Hadlock KG, Foung SK, Levy S. V(H)1-69 gene is preferentially used by hepatitis $C$ virus-associated $B$ cell lymphomas and by normal $B$ cells responding to the E2 viral antigen. Blood. 2001;97:1023-1026.

70. Quinn ER, Chan CH, Hadlock KG, Foung SK, Flint M, Levy S. The B-cell receptor of a hepatitis $\mathrm{C}$ virus (HCV)-associated non-Hodgkin lymphoma binds the viral E2 envelope protein, implicating HCV in lymphomagenesis. Blood. 2001;98:3745-3749.

71. Deisenhofer J. Crystallographic refinement and atomic models of a human Fc fragment and its complex with fragment B of protein A from Staphylococcus aureus at 2.9- and 2.8A resolution. Biochemistry. 1981;20:2361-2370. 


\section{Figure legends}

Figure 1. Immunophenotyping of expanded AtM in HCV-CV patients. (A) Representative flow cytometry plots showing the frequency of $C D 27^{+} \mathrm{CD} 21^{-} \mathrm{B}$ cells $(\mathrm{AtM})$ in HCV-CV patients compared to HCV-infected controls without CV and healthy donors (HD). Dot graph showing the frequency of AtM in $20 \mathrm{HCV}-\mathrm{CV}$ patients, $10 \mathrm{HCV}$ controls and $8 \mathrm{HD}$ (right). (B) Flow cytometry plots showing AtM and RM frequency in HCV-CV patients before and 12 weeks after HCV therapy (upper). Bar graph showing AtM and RM count changes upon HCV treatment in 6 HCV-CV patients (lower). (C) Representative flow cytometry plots showing Tbet expression among B cells (upper panels) and AtM frequency among Tbet ${ }^{+}$CD 19+ cells (lower panel) in HCV-CV patients, HCV controls and HD. Bar graph presenting percentage of AtM ${ }^{+}$Tbet $^{+} \mathrm{CD} 19^{+}$ cells in $6 \mathrm{HD}, 10 \mathrm{HCV}$ controls and $10 \mathrm{HCV}-\mathrm{CV}$ patients (right). (D) Flow cytometry histograms showing the differential expression of surface markers between AtM and $C D 27^{+} \mathrm{CD} 21^{+}$resting memory B cells (RM) from representative HCV-CV patient. (E) Bar graphs presenting the comparison of the surface markers expression showed in D between AtM and RM cells measured in nine HCV-CV patients. Mean values \pm SD are given. Mann-Whitney test was used to compare differences between two groups (Fig 1B and 1E). Multiple comparisons with more than two groups were performed using the Kruskal-Wallis test with p-values adjusted by the Bonferroni test (Dunn's method), in Fig $1 \mathrm{~A}$ and $1 \mathrm{C} .{ }^{*} \mathrm{p}<0.05 ;{ }^{* *} \mathrm{p}<0.01$.

Figure 2. Effects of TLR9 signaling on AtM in HCV-CVpatients. (A) Representative flow cytometry plots show the percentage of AtM from HCV-CV patients alone and simulated (anti$\mathrm{mu}+\mathrm{CD} 40 \mathrm{~L}$, or $\mathrm{CpG}$ ) positive for the different cytokines measured (upper panel). Bar graph comparing the mean percentage of $\mathrm{TNFa}^{+} \mathrm{AtM}$ in the 3 culture conditions measured for $4 \mathrm{HD}$, $4 \mathrm{HCV}$ controls and $7 \mathrm{HCV}-\mathrm{CV}$ donors (lower panel). Error bars indicate the SD. (B) Same as in (A) but for the \% of proliferating AtM. (C) Representative ELISA graph comparing the IgG1Fc reactivity of IgM produced in the supernatant of AtM or RM from HCV-CV patients and AtM from HCV controls and HD cultured alone and in the presence of CD40L and CpG. (D) Bar graphs presenting different expression of surface markers on Atm cells of HD $(n=4), H C V$ 
controls $(n=4)$ and HCV-CV patients $(n=7)$ cultured alone and simulated (anti-mu+CD40L or $\mathrm{CpG}$. Mean values $\pm \mathrm{SD}$ are given. Multiple comparisons with more than two groups were performed using the Kruskal-Wallis test with p-values adjusted by the Bonferroni test (Dunn's method).

Figure 3. Effects of CpG-stimutated AtM on effector and regulatory T-cell subsets. (A) Representative flow cytometry plot shows the percentage of $\mathrm{CD} 4^{+} \mathrm{IFNy}{ }^{+} \mathrm{T}$ cells alone and after co-culture with AtM stimulated or not with $\mathrm{CpG}$ and with the addition of anti-TNFa in the coculture (left). Bar graph comparing the mean percentage of $C D 4^{+} I F N y^{+} T$ cells in the 4 culture conditions measured for $6 \mathrm{HCV}-\mathrm{CV}$ patients (right). Error bars indicate the SD. (B) Same as for $(A)$ but for the mean percentage of CD4 ${ }^{+} \mathrm{TNFa}^{+} \mathrm{T}$ cells. (C) Same as for $(A)$ but for the mean percentage of CD4+IL17A+ $\mathrm{T}$ cells measured for $6 \mathrm{HCV}-\mathrm{CV}$ patients. (D) Representative flow cytometry histogram shows the CFSE proliferation of sorted CD4 ${ }^{+} \mathrm{CD} 25^{-} \mathrm{T}$ cells alone or in co-culture with AtM from HCV-CV patients (top). Bar graph comparing the mean percentage of proliferating $\mathrm{CD}^{+}{ }^{+} \mathrm{CD} 25^{-} \mathrm{T}$ cells (Teff) alone or co-cultivated with AtM for 6 HCV-CV patients (bottom). Error bars indicate the SD. (E) Same as for (D) but for the mean percentage of proliferating $\mathrm{CD}^{+} \mathrm{CD}^{2} 5^{\text {hi }} \mathrm{CD} 127^{\text {low }} \mathrm{FOXP3}{ }^{+} \mathrm{T}$ cells (Treg). Mean values $\pm \mathrm{SD}$ are given. MannWhitney test was used to compare differences between two groups (Fig 3D and 3E). Multiple comparisons with more than two groups were performed using the Kruskal-Wallis test with pvalues adjusted by the Bonferroni test (Dunn's method), in Fig 3A, 3B and $3 C$ ). ${ }^{*} p<0.05$.

Figure 4. Gene profiling of HCV-CV AtM in response to TLR9 stimulation. (A) Heatmap showing the differential expression (fold change $>2$ ) of 219 genes between unstimulated and CpG-stimulated AtM from three HCV-CV patients. (B) Bar graph showing the cellular pathways containing up- (red) and down- (blue) regulated transcripts in CpG-stimulated AtM. (C) Diagram shows one of the top network, centered on both TNF and STAT3, which was identified by functional enrichment on the top molecular function activated in CpG-stimulated AtM. Links 
of up- (red) and down- (blue) regulated genes of the 219 gene signature with TNF and STAT3 molecules are indicated in orange and purple, respectively.

Figure 5. Immunoglobulin gene repertoire of AtM. (A) Flow cytometry plots show the staining of patients' PBMC with fluorescently labeled antibodies used for the identification and single sorting of AtM. (B) Pie charts show clonal expansions of AtM. The total number of analyzed memory B-cell antibodies is indicated in the center, each pie slice represents a clonal family and the area of the slice is proportional to the number of clonal relatives. Each clonal family is represented by the same color and unique members are not colored. (C) Phylogenic trees of the AtM clonal expansions. GL, putative germline precursor sequence. Clonal members expressed as recombinant antibodies are indicated on the phylogeny. (D) Schematic diagram indicates the $\mathrm{V}_{H} D_{H} J_{H}$ and $V_{\kappa} J_{\kappa}$ genes, and $\lg \mathrm{H} / \lg \mathrm{L}$ CDR3s as consensus sequences from all the members in each clonal expansion. (E) Dot plots show for each patient, the numbers of mutations in $\mathrm{V}_{\mathrm{H}}$ and $\mathrm{V}_{\kappa}$ genes of AtM. The average number of mutations is indicated below each dot plot. (F) Graphs show the Bayesian estimation of antigen-driven selection of the Ig sequences in clonal B-cell families. Values $>0$ indicate positive selection.

Figure 6. Antibody reactivities of AtM. (A) ELISA graphs show the reactivity of AtM antibodies expressed as recombinant $\lg M, \lg G 1$ and $\lg M$ Fab fragments against the human IgG1 Fc. (B) Immunoblotting showing the reactivity of AtM antibodies against the human IgG1 Fc. L, protein ladder indicating molecular masses. (C) Graphs show the ELISA reactivity of IgM antibodies to $\lg \mathrm{G} 1-\mathrm{Fc}$ overlapping peptides. The values of grand average of hydropathy (GRAVY) for all peptides are indicated below. (D) Heat map showing the reactivity of AtM IgG and IgM antibodies against various purified antigens and HEp-2 cells lysate to detect polyreactive binding by ELISA. Color intensity is proportional to the reactivity level with darker red colors indicating high binding while light colors show moderate binding (white = no binding). $\mathrm{C}_{+}$, positive control; C-, negative control. (E) Graphs show the reactivity of recombinant IgG and IgM AtM antibodies against HCV proteins. 
Figure 7. Mapping of RF epitopes on the human IgG1-Fc. (A) ELISA graphs comparing the binding of selected AtM IgM antibodies to wildtype (straight lines) and N297A mutant (dotted lines) Fc molecule. (B) ELISA graphs show the binding of selected recombinant IgM to human IgG-Fc protein in presence of purified protein $A$ as a potential competitor. (C) ELISA graphs comparing the $\lg M$ binding to wildtype human $\lg \mathrm{G} 1$ and $\lg \mathrm{G} 3 \mathrm{Fcs}$, and to swapped $\lg \mathrm{G} 1-3$ and IgG3-1 molecules. (D) The schematic diagram (based on the PDB-1FC2 structure(71)) shows putative antibody binding sites on human Fc. Fc $\mathrm{N}$-glycans and bound protein A are shown in yellow and red, respectively. 


\section{Lay summary}

B cells are best known for their capacity to produce antibodies, which often play a deleterious role in the development of autoimmune diseases.

During chronic hepatitis C, deleterious B cells proliferate and can be responsible for autoimmune symptoms (arthritis, purpura, neuropathy, renal disease) and/or lymphoma.

Direct-acting antiviral therapy clears the hepatitis $\mathrm{C}$ virus and eliminates deleterious $\mathrm{B}$ cells. 
Figure 1

A
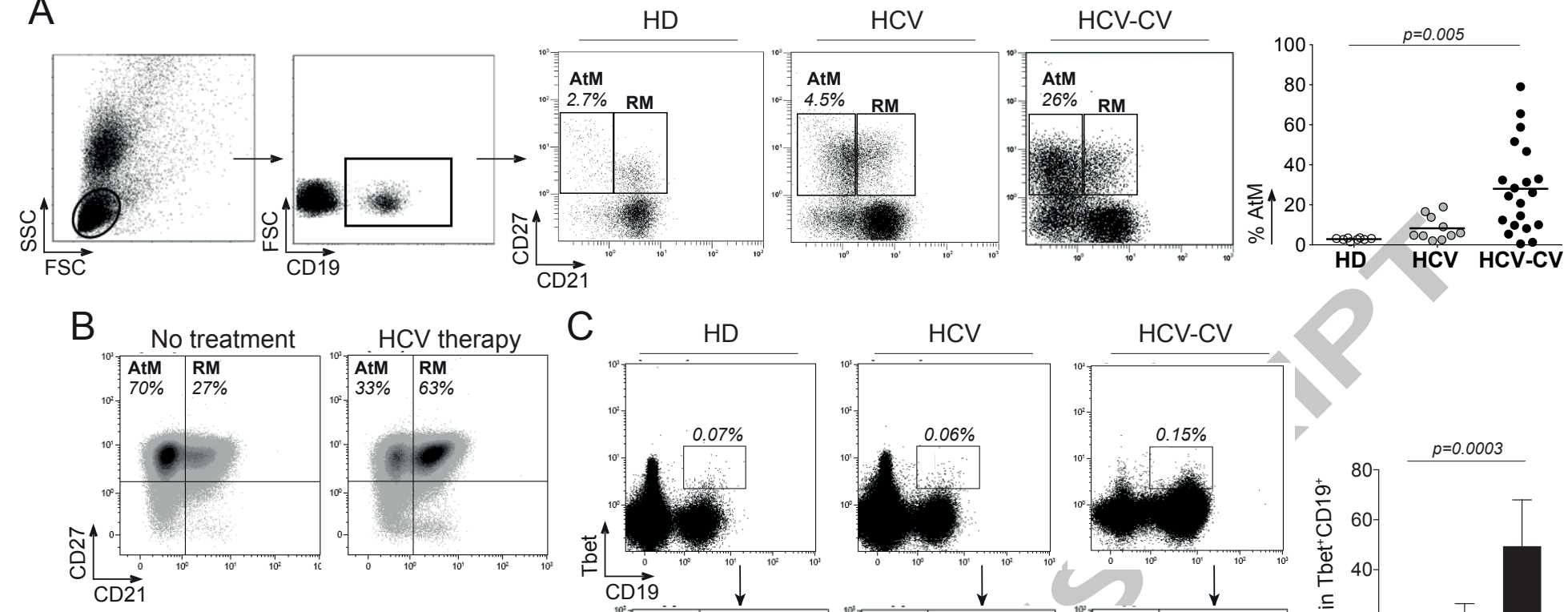

C
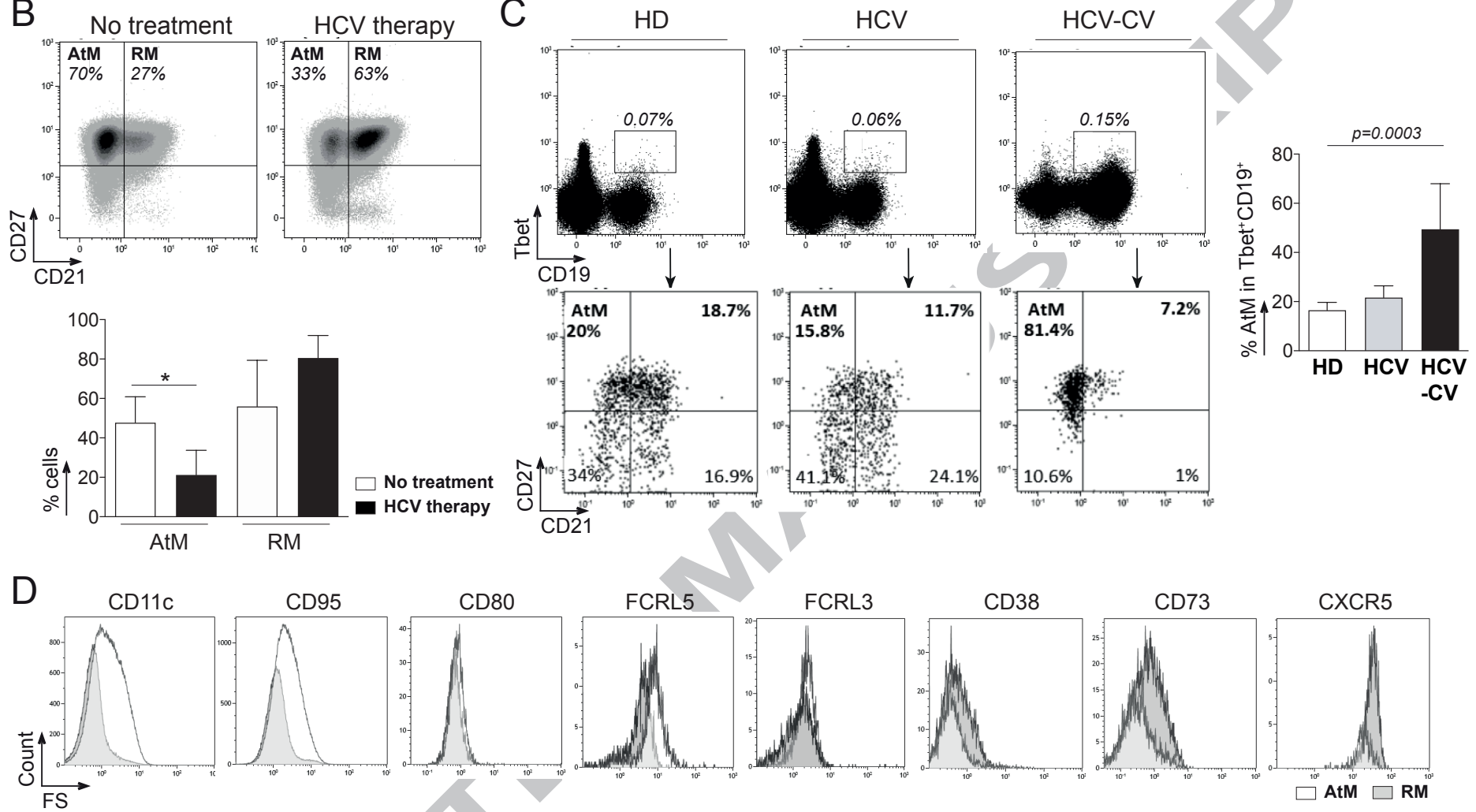

CD95
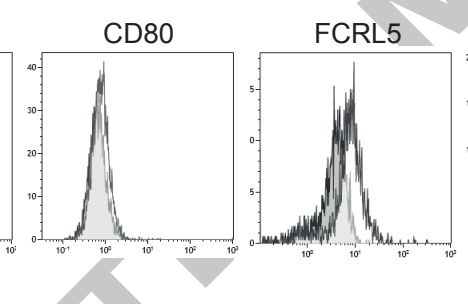

FCRL3

CD38
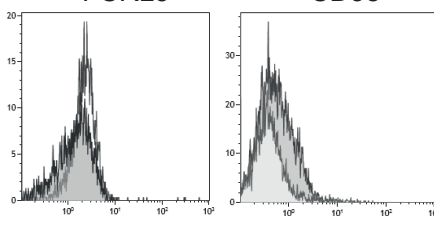

CD73

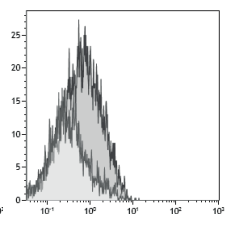

CXCR5

E
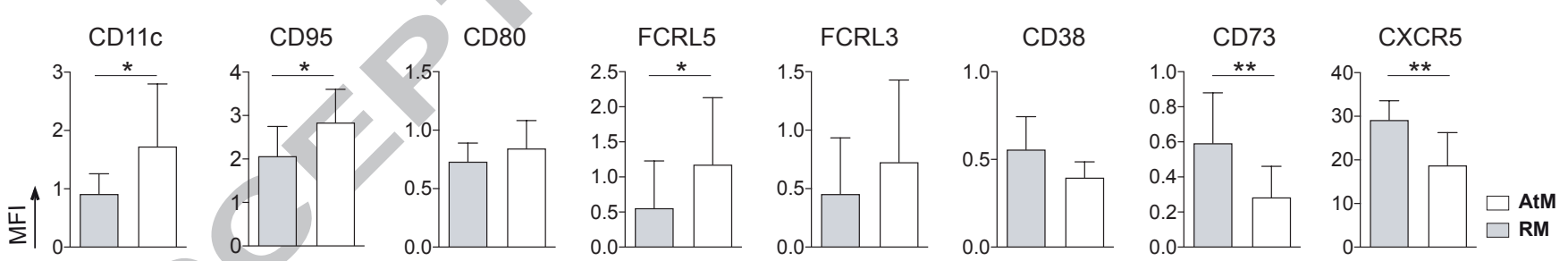


\section{Figure 2}

A
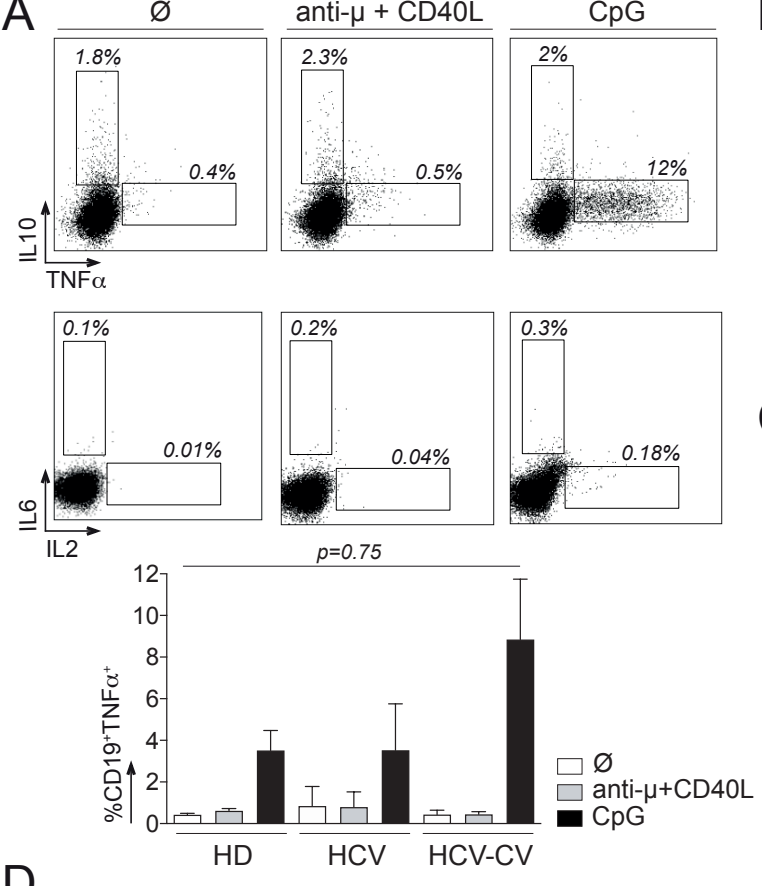

B
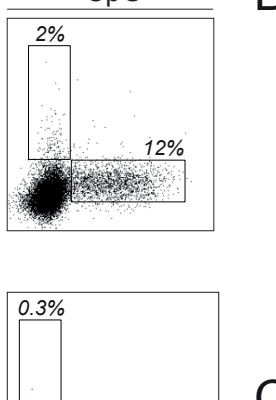

D

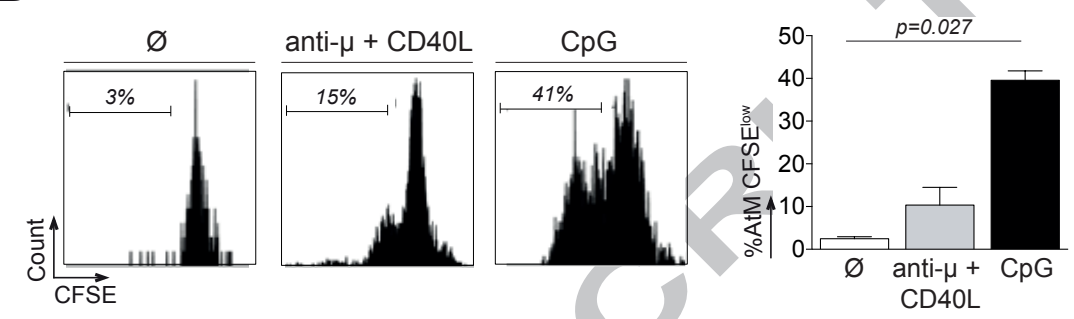

C
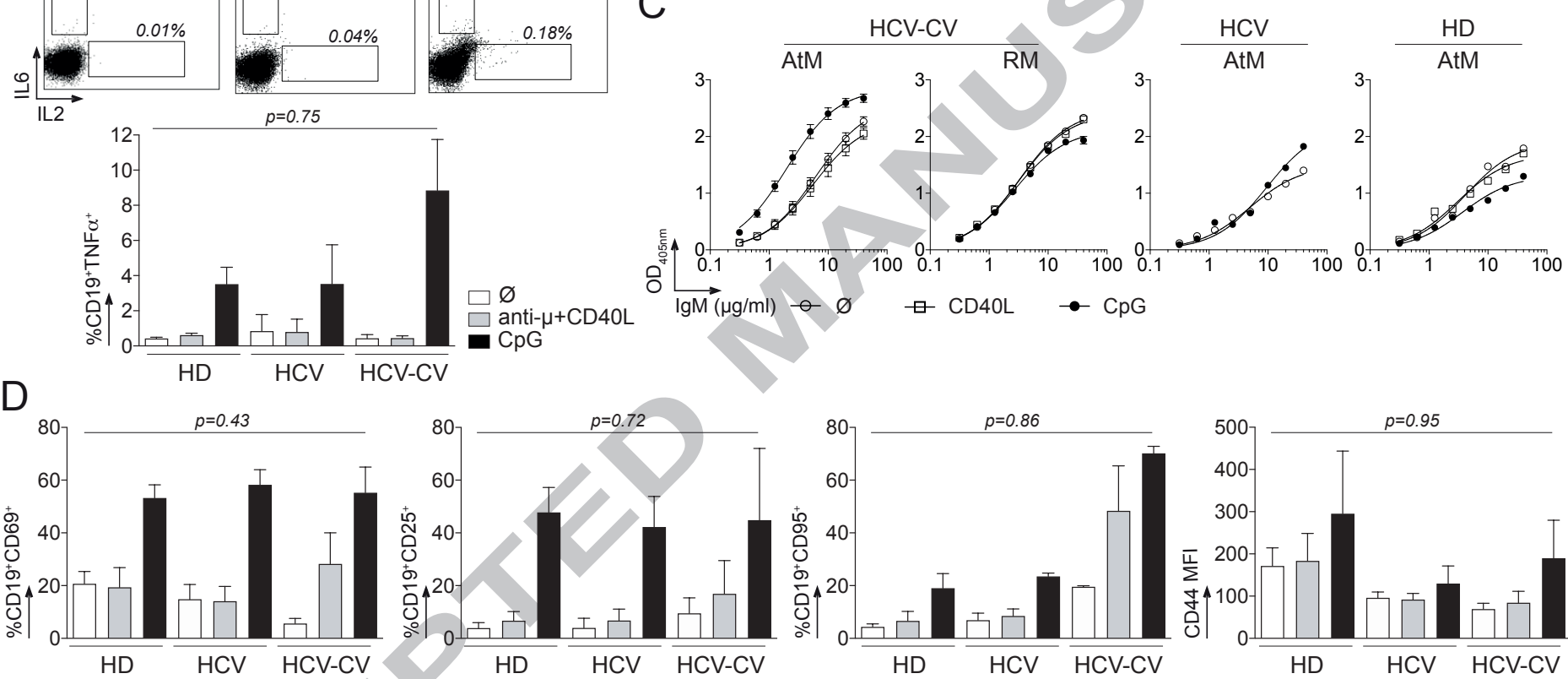

$\square \varnothing \quad \square$ anti- $\mu+C D 40 \mathrm{D}$ CpG 
Figure 3

A $\mathrm{CD} 4{ }^{+} \mathrm{CD} 25$

A CD27 ${ }^{+}$CD21- (AtM)

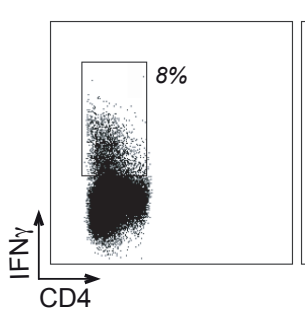

\begin{tabular}{cc} 
CpG \\
\cline { 2 - 2 } anti-TNF $\alpha$
\end{tabular}

B
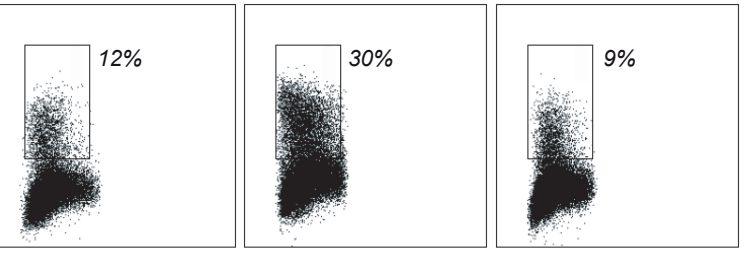

$\mathrm{CD} 4{ }^{+} \mathrm{CD} 25$

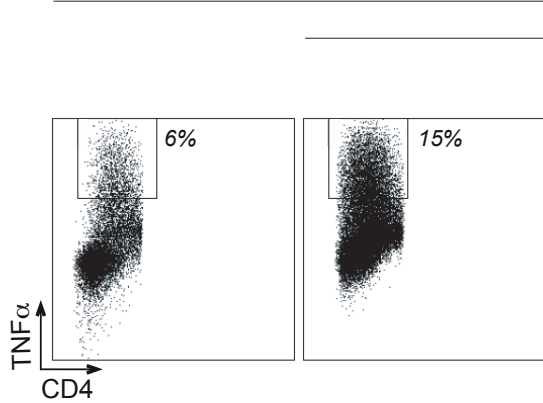

CD27 ${ }^{+} \mathrm{CD} 21^{-}$(AtM)
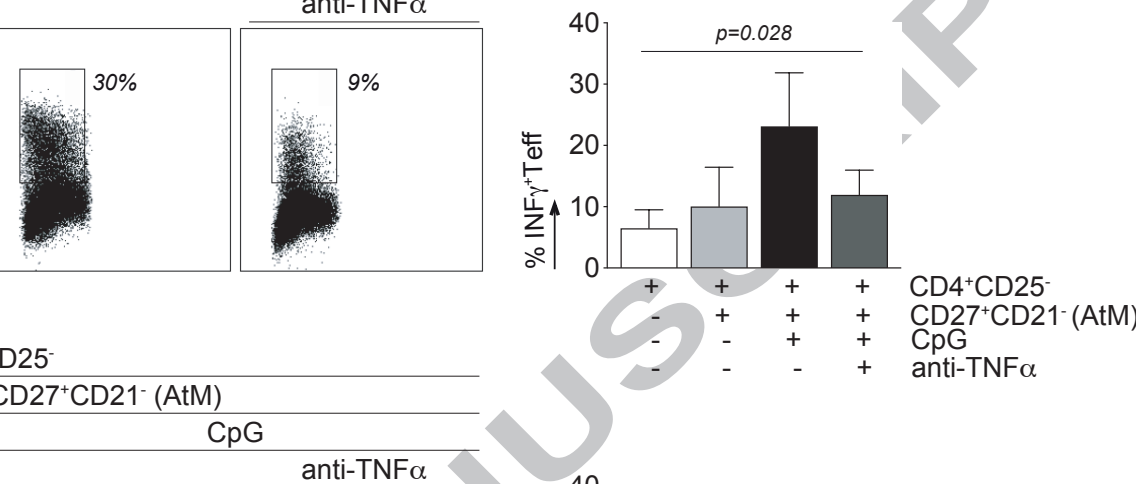

C

$\mathrm{CD} 4{ }^{+} \mathrm{CD} 25-$
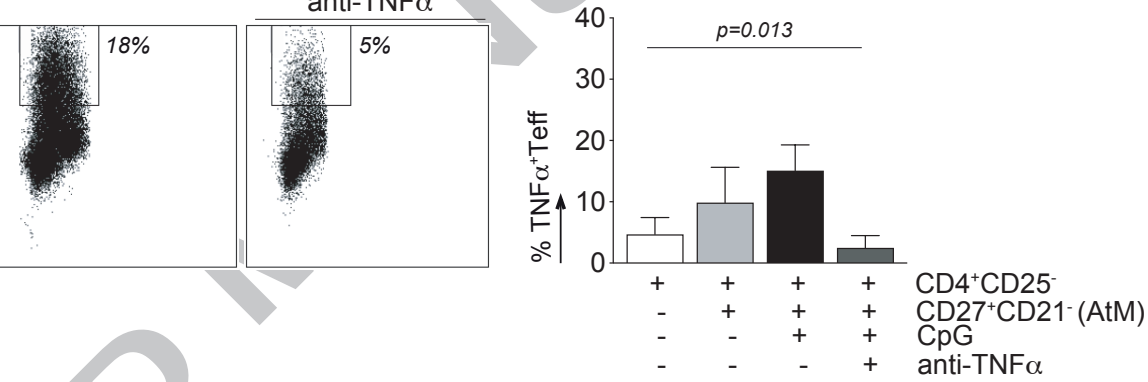
CD27 ${ }^{+}$CD21- (AtM)
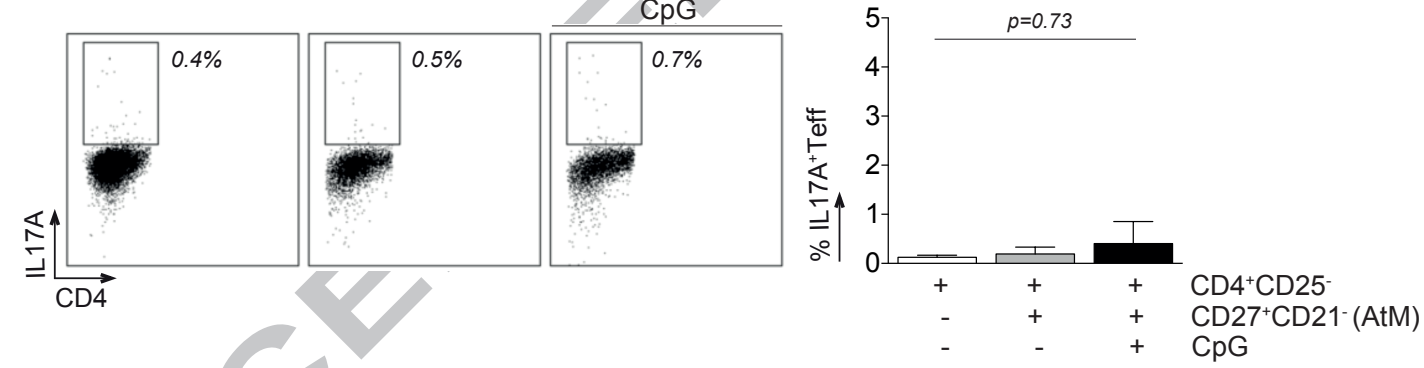

D

$\mathrm{CD} 4{ }^{+} \mathrm{CD} 25$
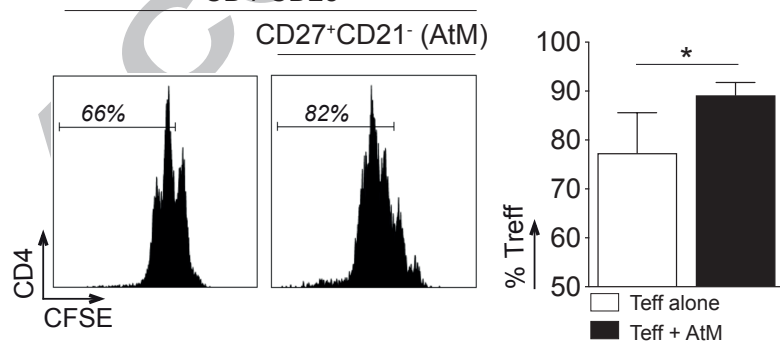

E $\mathrm{CD} 4^{4} \mathrm{CD} 25^{\mathrm{h}} \mathrm{CD} 127^{\mathrm{low}} \mathrm{FOXP} 3^{+}$

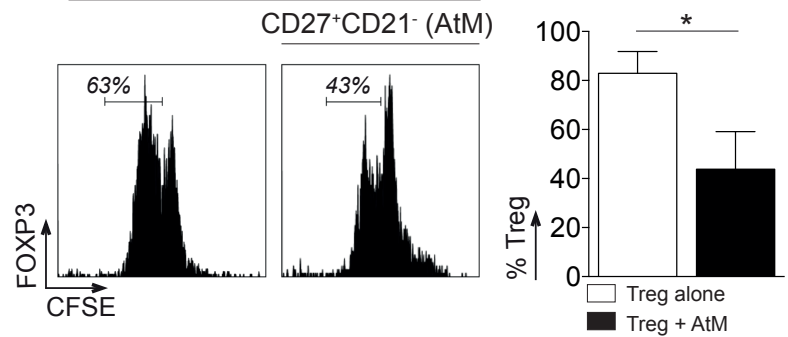




\section{Figure 4}

A

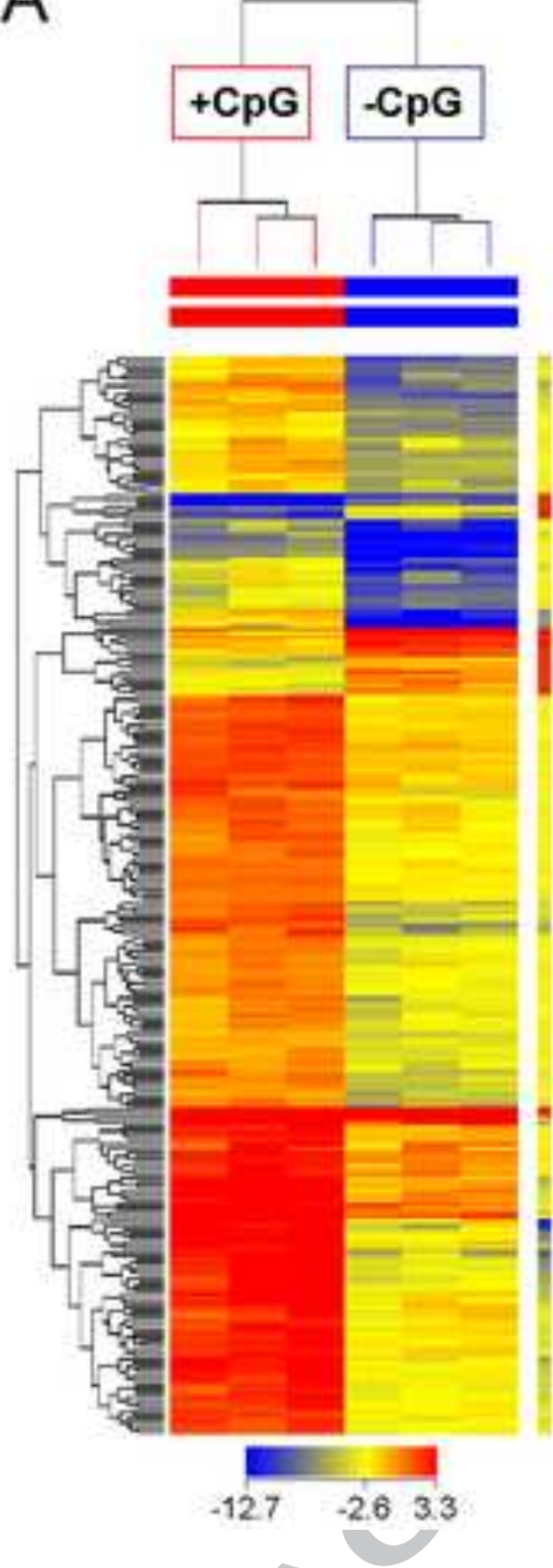

B

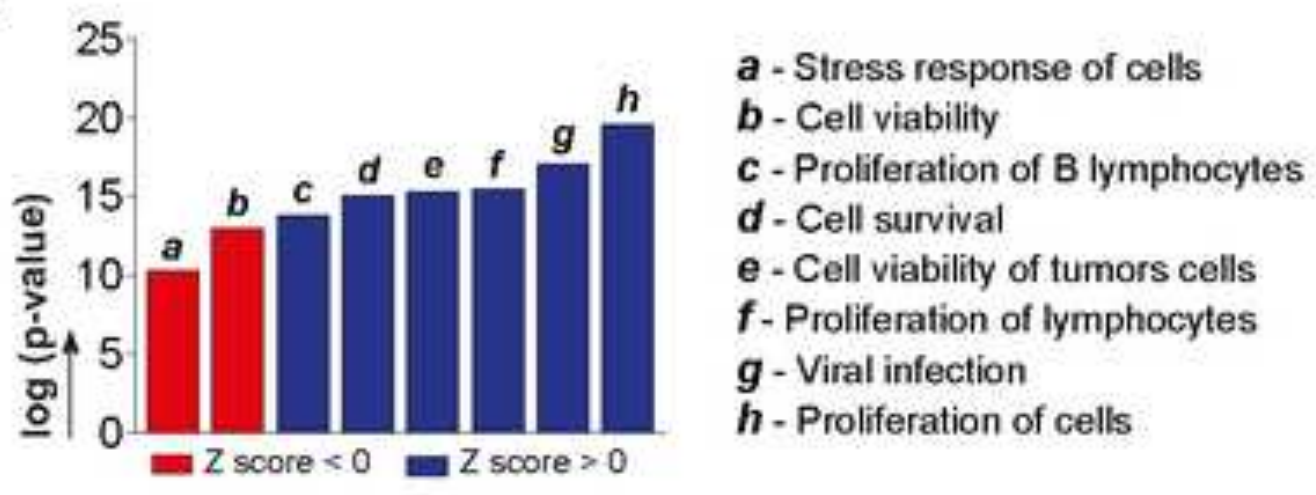

STAT 3

TNF

FAIMB

CD47

NFATC1

IL2RA

MIR155HG

PFKFB4

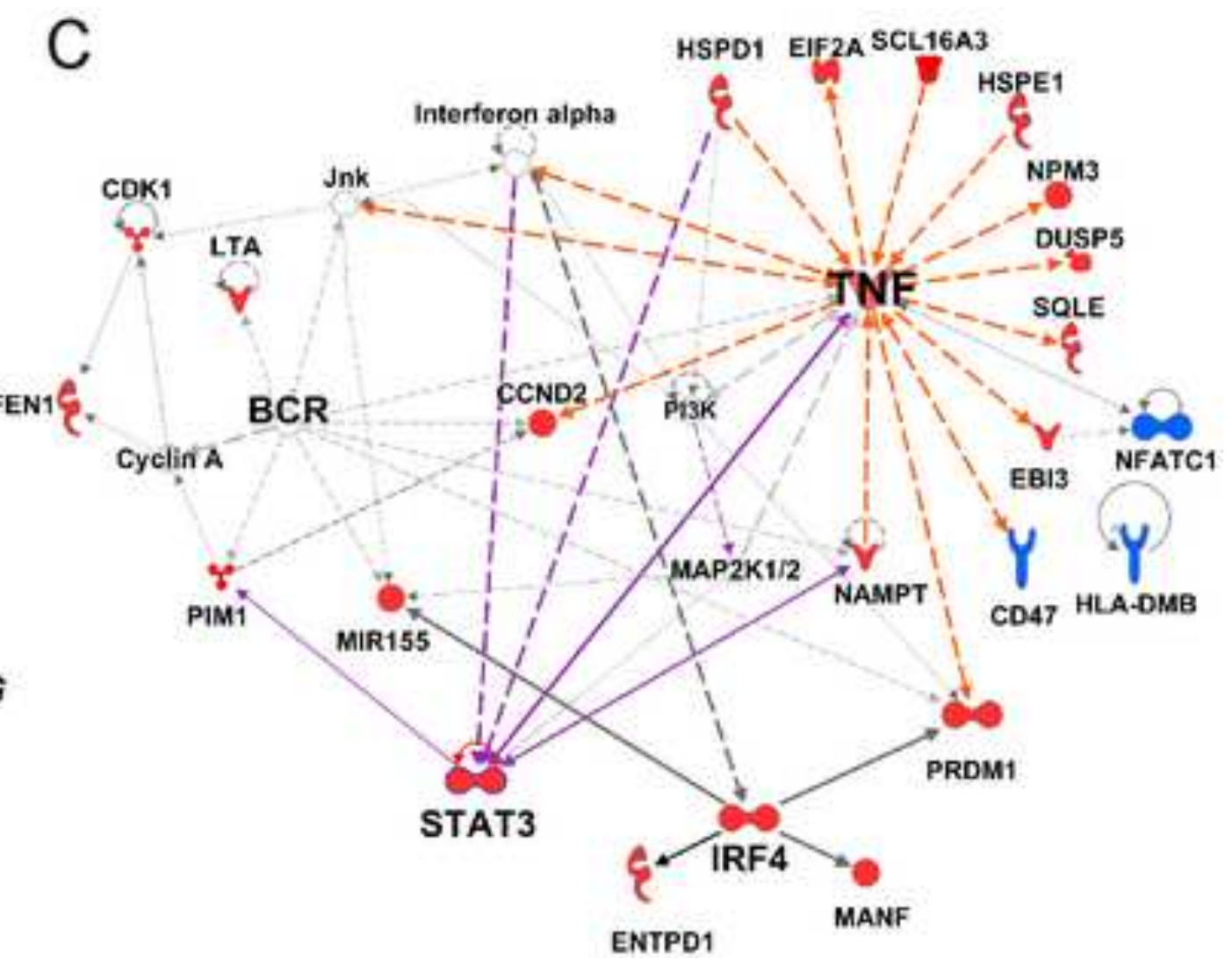




\section{Figure 5}

\section{ACCEPTED MANUSCRIPT}

A
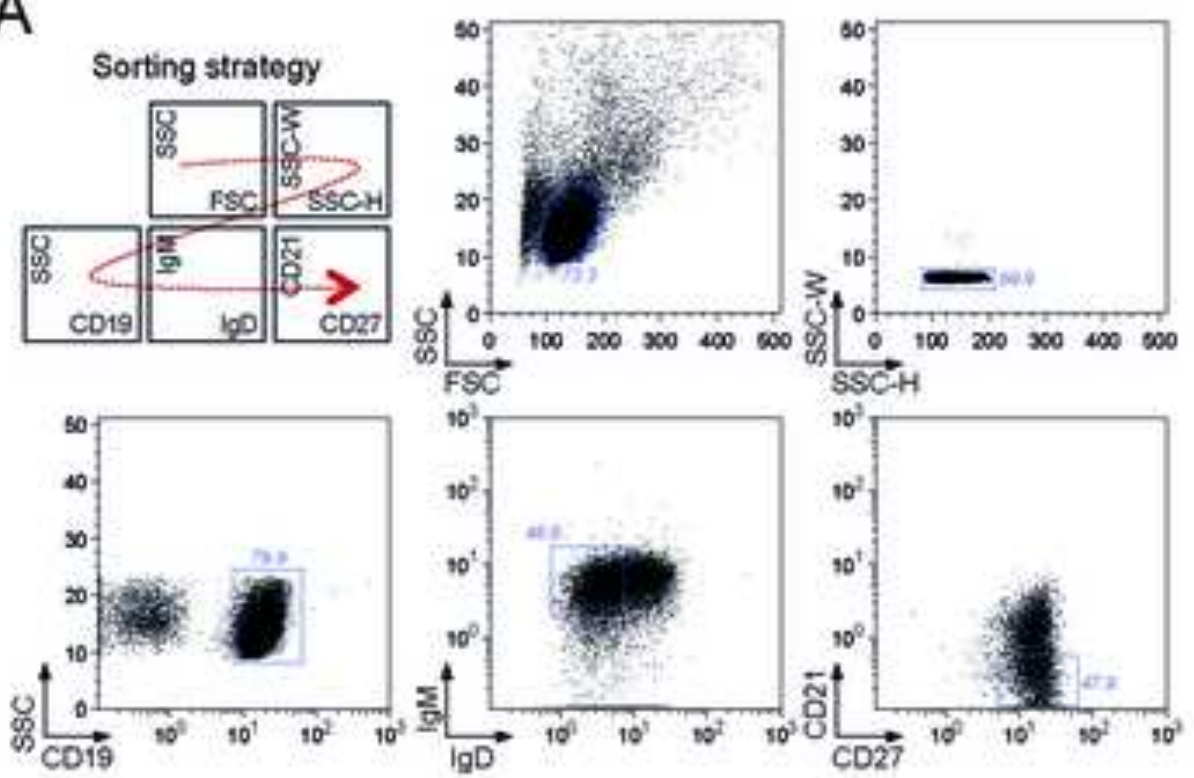

B

pt1

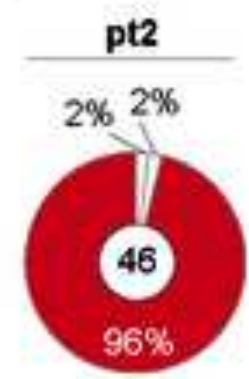

C
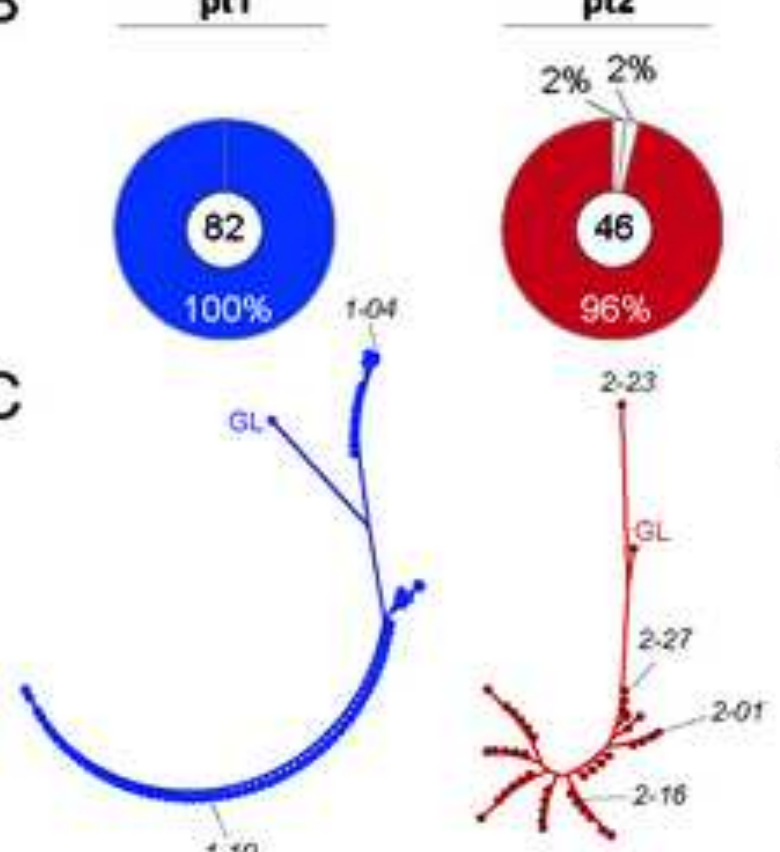

D pt1 $1.693-104$ CYDCEIYYYFF $33.20=$ OYCSSPYT

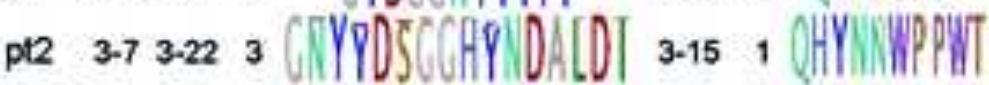

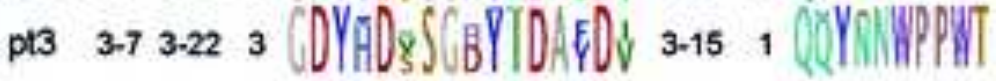
$E$

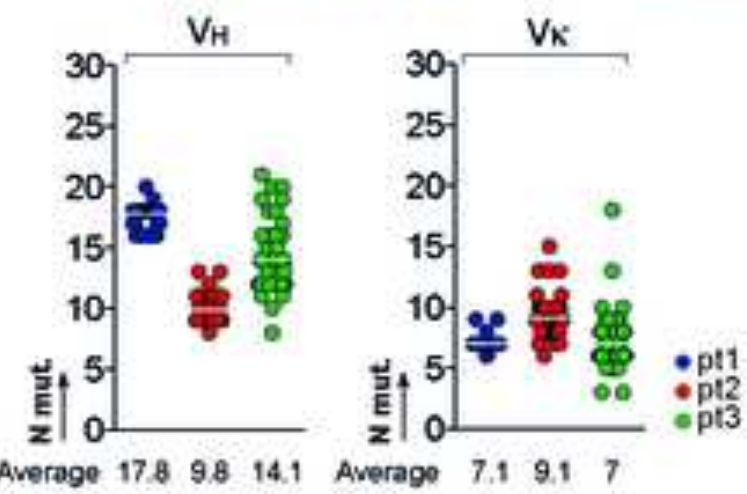

$\mathrm{F}$

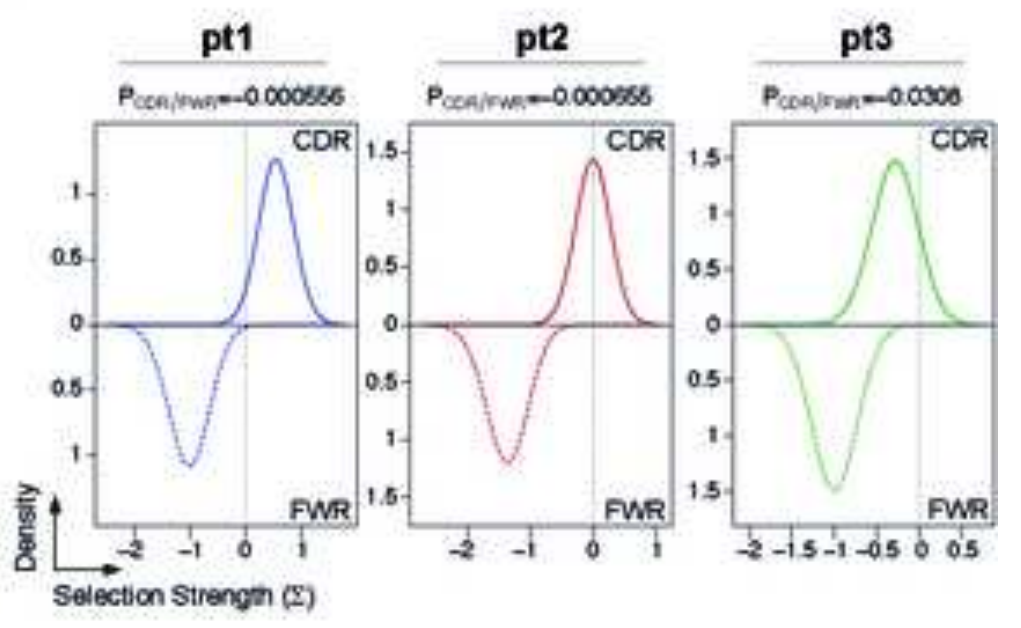




\section{Figure 6}

A
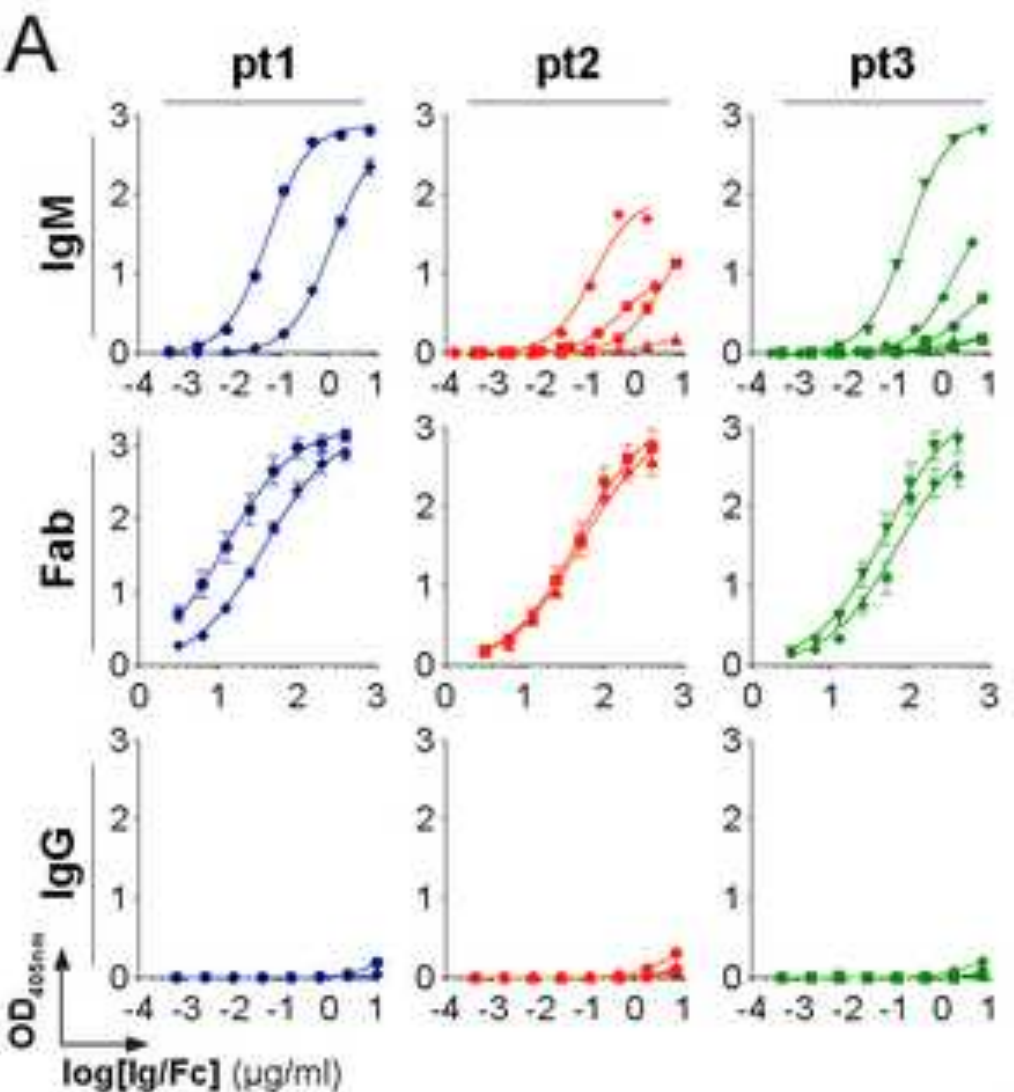

D
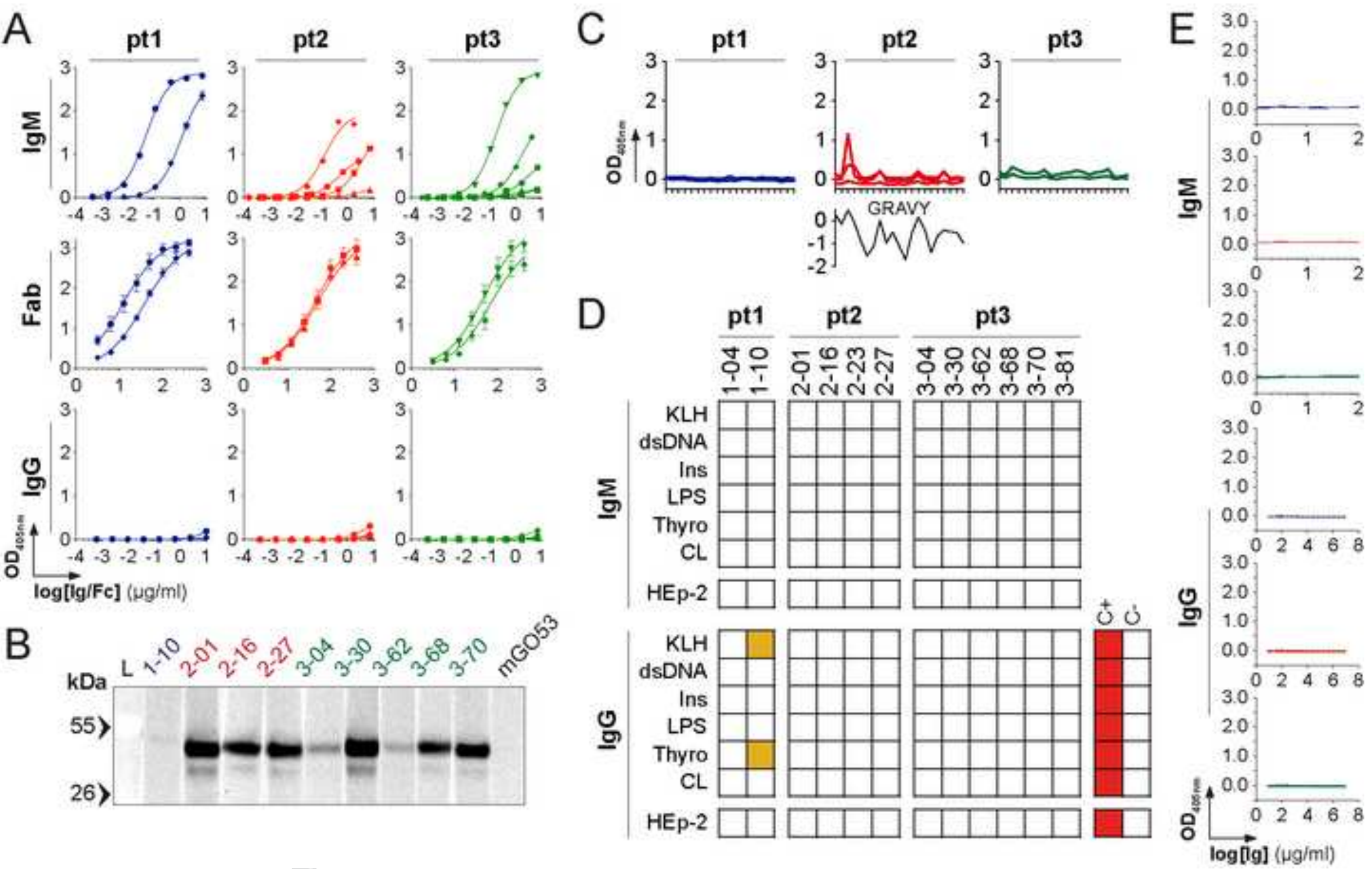


\section{Figure 7}

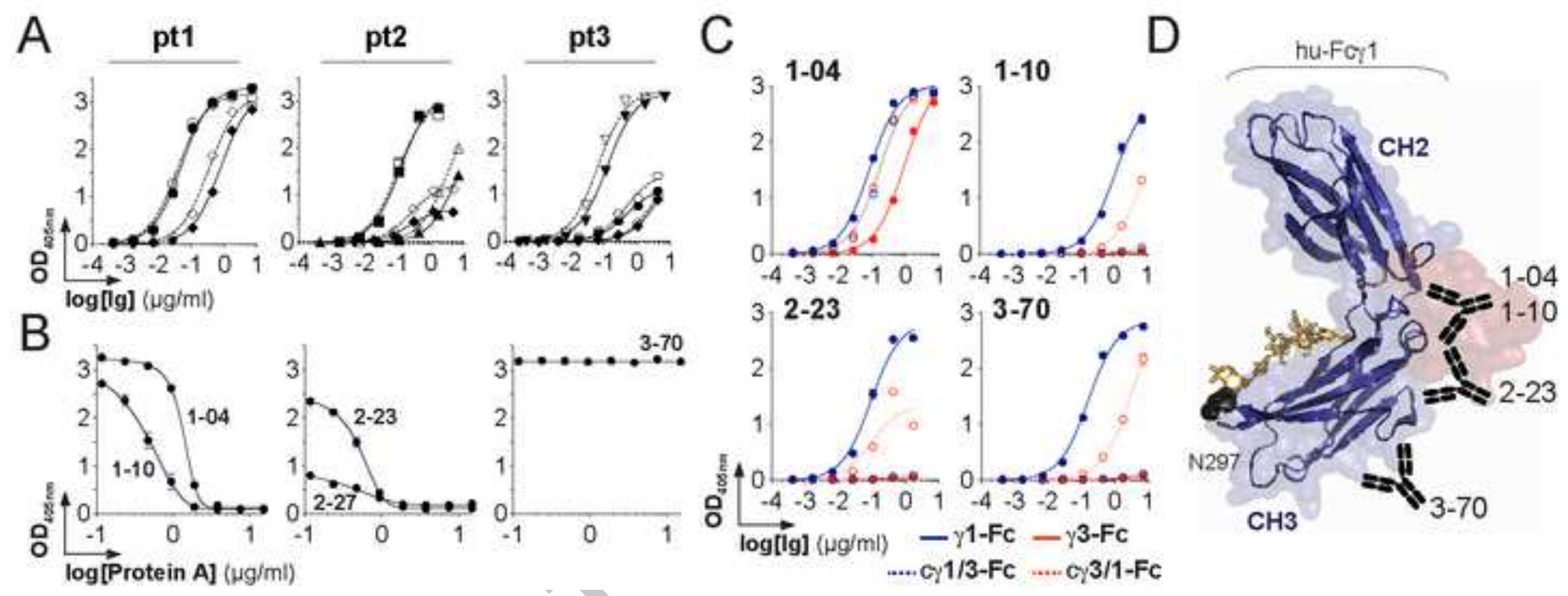


Table 1. Demographic and clinical characteristics of patients with active HCV-CV or HCV alone.

\begin{tabular}{|c|c|c|}
\hline Characteristics & $\begin{array}{c}\mathrm{HCV}-\mathrm{CV} \\
\mathrm{N}=20\end{array}$ & $\begin{array}{l}\mathrm{HCV} \\
\mathrm{N}=10\end{array}$ \\
\hline Age, years & $57[51-64]$ & $54[48-60]$ \\
\hline Male gender (n, \%) & $11(55)$ & $6(60)$ \\
\hline \multicolumn{3}{|l|}{ HCV genotype $(n, \%)$} \\
\hline 1 & $12(60)$ & $6(60)$ \\
\hline 2 & $1(5)$ & $1(10)$ \\
\hline 3 & $2(10)$ & $1(10)$ \\
\hline 4 & $5(25)$ & $2(20)$ \\
\hline 5 & 0 & 0 \\
\hline \multicolumn{3}{|l|}{ Metavir liver fibrosis score (n, \%) } \\
\hline Stage 1 & $1(5)$ & $2(20)$ \\
\hline Stage 2 & $6(30)$ & $3(30)$ \\
\hline Stage 3 & $4(20)$ & $2(20)$ \\
\hline Stage 4 & $9(45)$ & $3(30)$ \\
\hline Baseline HCV RNA $(\log 10 \mathrm{IU} / \mathrm{mL})$ & $5.4[4.8-6.5]$ & $5.9[5.6-6.2]$ \\
\hline ALT level (IU/L) & $67[41-79]$ & $55[49-61]$ \\
\hline Serum cryoglobulin level (g/L) & $0.37[0.16-0.89]$ & NA \\
\hline Serum C4 level (g/L) & $0.07[0.03-0.15]$ & NA \\
\hline $\begin{array}{l}\text { Serum rheumatoid factor level } \\
(\mathrm{IU} / \mathrm{mL})\end{array}$ & $31[11-79]$ & NA \\
\hline Purpura (n, \%) & $17(85)$ & NA \\
\hline Skin ulcer $(\mathrm{n}, \%)$ & $3(15)$ & NA \\
\hline Polyneuropathy (n, \%) & $11(55)$ & NA \\
\hline Kidney involvement $(n, \%)$ & $5(25)$ & NA \\
\hline
\end{tabular}

Values are expressed as medians [IQR].

ALT, alanine aminotransferase; HCV, hepatitis C virus; NA, not applicable 


\section{ANERGY}

RF AUTOANTIBODIES

Clonal expansion FCRLIIM $\frac{\Delta}{C D}$ VUSCOSD $\mathrm{HCV}^{+}$
$\mathrm{Cryo}$ 2. of AtM B cells
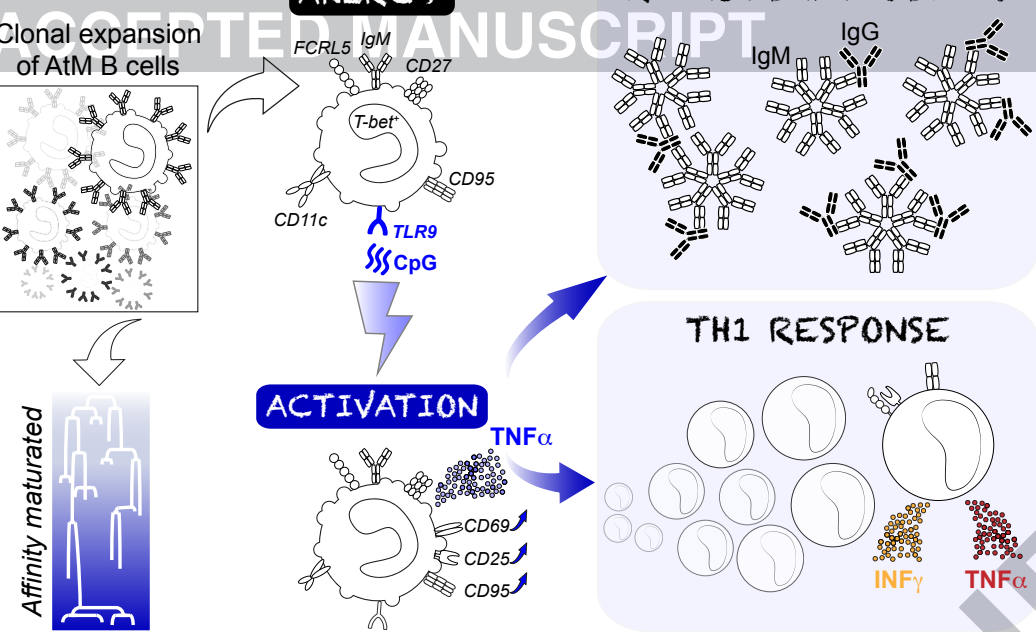

\section{ACTIVATION}

$\mathrm{TNF} \alpha$

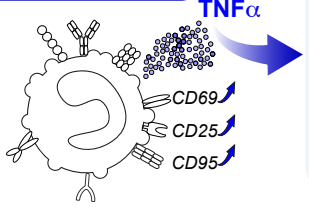

THI RESPONSE

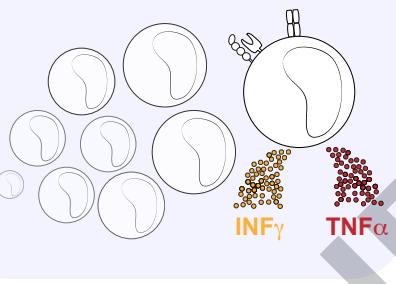




\section{Highlights}

- TLR-9 activation of atypical memory B (AtM) cells have central role in breaking tolerance in HCV-CV patients.

- TLR9 signaling on AtM, via the secretion of TNFa, have deleterious effects by stimulating proliferation and activation of effector Th1 cells

- Rheumatoid factors molecules produced by AtM recognized distinct IgG-Fc epitopes and do not cross-reacted against $\mathrm{HCV}$ proteins, confirming that molecular mimicry between $\mathrm{HCV}$ and human IgG proteins is not the trigger of $\mathrm{HCV}$-associated autoimmunity.

- Atypical memory cells largely disappear after antigen removal by DAA therapy 